\title{
The Role of Overbilling in Hospitals' Earnings Management Decisions
}

\section{Citation}

Heese, Jonas. "The Role of Overbilling in Hospitals' Earnings Management Decisions." European Accounting Review 27, no. 5 (2018).

\section{Published Version}

https://doi.org/10.1080/09638180.2017.1383168

\section{Permanent link}

http://nrs.harvard.edu/urn-3:HUL.InstRepos:41845078

\section{Terms of Use}

This article was downloaded from Harvard University's DASH repository, and is made available under the terms and conditions applicable to Open Access Policy Articles, as set forth at http:// nrs.harvard.edu/urn-3:HUL.InstRepos:dash.current.terms-of-use\#OAP

\section{Share Your Story}

The Harvard community has made this article openly available.

Please share how this access benefits you. Submit a story.

Accessibility 


\section{The Role of Overbilling in Hospitals' Earnings Management Decisions}

Jonas Heese

Working Paper 18-026 


\title{
The Role of Overbilling in Hospitals' Earnings Management Decisions
}

\author{
Jonas Heese
}

Harvard Business School

Working Paper 18-026 


\title{
The Role of Overbilling in Hospitals' Earnings Management Decisions
}

\author{
Jonas Heese* \\ Harvard University \\ jheese@hbs.edu
}

Received: December 2016; accepted: September 2017.

\begin{abstract}
This paper examines the role of overbilling in hospitals' earnings management choices. Overbilling by hospitals is a form of revenue manipulation that involves misclassifying a patient into a diagnosis-related group that yields higher reimbursement. As overbilling allows hospitals to increase revenues without altering operations, affecting costs, or having to reverse such behavior in the future, I propose and find that overbilling reduces hospitals' use of managing accruals or cutting discretionary expenditures. Next, I find that hospital managers prefer overbilling to managing accruals (cutting discretionary expenditures) when cutting discretionary expenditures (managing accruals) is constrained, and vice versa. Collectively, my findings suggest that overbilling is an important alternative manipulation tool in hospitals.
\end{abstract}

Keywords: Overbilling, accrual-based earnings management, real activities manipulation, forprofit hospitals

JEL classification: I11, I18, M41, M48

Acknowledgements: I thank the editor and two anonymous referees for insightful comments that have significantly improved this paper. I also appreciate helpful suggestions from Margaret Abernethy, Ge Bai, Paul Healy, Elina Heese, Thomas Keusch, Frank Moers, Karthik Ramanna, Naomi Soderstrom, Patrick Vorst, and Anne Wyatt. I also thank workshop participants at Monash University, University of Melbourne, University of Queensland, University of Technology at Sydney, University of Western Australia, and the 2013 Global Management Accounting Research Symposium (GMARS) for their helpful comments.

* jheese@ hbs.edu. Harvard University, Soldiers Field Road, Boston, MA 02163, USA. Phone: 617-495-2827. Fax: 617-496-7387.

Paper accepted by Daniel Beneish. 


\section{Introduction}

In this paper, I examine the role of overbilling in hospitals' earnings management choices. Hospitals engage in overbilling when they classify patients' ailments as more severe than they are to earn higher revenues without changing the actual treatment. Such behavior is made possible by the information asymmetry between hospitals and insurers regarding patients' conditions, and is an acknowledged problem in the U.S. healthcare industry with costs ranging from $\$ 23.2$ billion in 1996 to $\$ 77.4$ billion in 2014 as highlighted by the U.S. Government Accountability Office (GAO, 2000, 2013, 2015) and the U.S. Department of Health and Human Services (HHS, 2013). Overbilling encompasses a broad set of actions, ranging from liberal interpretation of rules to, at the extreme, outright manipulation of the patient record (Dafny \& Dranove, 2009; Heese, Krishnan, \& Moers, 2016).

In prior examination of organizations' earnings management strategies, accounting research has typically focused on earnings management via accruals and real activities such as cutting expenditures (e.g., Healy \& Wahlen, 1999; Roychowdhury, 2006). Overbilling via misclassifying patients' ailments, however, has advantages over managing accruals and cutting discretionary expenditures, because it allows hospitals to increase actual revenues without altering operations, affecting costs directly, or having to reverse such behavior in the future. In contrast, cutting discretionary expenditures requires changing the hospital's operating activities, and managing accruals involves judgment in the application of reporting methods without generating cash flows. Following these arguments, I propose that overbilling reduces hospitals' use of accrual-based or real activities earnings management.

I begin my investigation by validating a measure of overbilling. Following Heese et al. (2016), I focus on three distinct diagnosis-related group (DRG) families identified by the Office 
of the Inspector General (OIG, 1998) of the HHS as being prone to overbilling: "General respiratory ailments" (DRG family 79), "circulatory system disorders" (DRG family 144), and “diabetes and metabolic disorders" (DRG family 296). ${ }^{1}$ DRG family 79 offers the highest financial incentives to overbill, as hospitals can generate up to $\$ 5,000$ in revenue by misclassifying a single patient from the lowest- to the highest-paying DRG within that family. In comparison, hospitals can generate "only" up to $\$ 3,750$ and $\$ 1,750$ per overbilled patient in DRG families 144 and 296, respectively. Overbilling can have a substantial impact on performance. For instance, if the average hospital misclassifies all patients from the lowest- to the highestpaying DRGs within each family, it can generate about $\$ 2.3$ million in additional revenue per year, which is $3.9 \%$ of the average net patient revenue or $48.7 \%$ of the average net income (after adjusting the $\$ 2.3$ million for an assumed tax rate of 30\%). My empirical tests are based on patient records of Californian for-profit hospitals for 1996-2007. I end the sample in 2007, when new DRGs were introduced, making it difficult to compare overbilling behavior across DRG regimes as stated by the Centers for Medicare and Medicaid Services (CMS, 2010).

I use ordinary least squares (OLS) regressions to separate hospitals' abnormal billing from normal billing. To that end, I regress—-separately for each of the three DRG families - the percentage of patients coded into the highest-paying DRG on underlying patient and hospital characteristics that prior studies find to be associated with the normal level of billing. For instance, I control for the health status of patients, because more-severely ill patients are

\footnotetext{
${ }^{1}$ DRGs identify patients with similar conditions who require similar resources for treatment; they are used for reimbursement by major insurance programs such as Medicare (Clemens \& Gottlieb, 2015; Heese et al., 2016). A DRG family is a group of DRGs associated with the same underlying ailment. The name of the family (e.g., DRG family 79) reflects the DRG (e.g., DRG 79) that generates the highest reimbursement within the family. Reimbursements for DRGs within a DRG family differ because the treatment of patients with the same underlying ailment (e.g., respiratory ailments) can differ based on the patient's health status and other complicating factors.
} 
rightfully assigned to the higher-paying DRGs, as their treatment is more costly. I use the residuals from these models as the measures of abnormal billing.

I run three tests to validate these overbilling measures. First, I examine the relation between these measures and hospitals' operating cash flows, because overbilling increases cash collections. I find that overbilling in DRG families 79 and 144 is associated with higher operating cash flows. Second, to more directly assess whether hospitals use overbilling to manage their earnings, I examine the relation between overbilling measures and hospitals' M-Scores. The MScore (Beneish, 1999) is a proxy to identify firms likely to manipulate their earnings. If overbilling is used to manipulate earnings, I should observe a positive relation between the overbilling measures and hospitals' M-Scores. I find support for this relation for the two highestpaying DRG families (i.e., DRG families 79 and 144). Third, I test whether overbilling is associated with traditional indicators of earnings manipulation and find that hospitals that meet the zero-earnings benchmark overbill in DRG family 79.

Second, I examine whether hospitals decrease their involvement in real or accrual earnings management when they overbill. Following Eldenburg, Gunny, Hee, and Soderstrom (2011), I measure real activities manipulation (RAM) as the extent to which hospitals cut expenditures in non-operating areas (e.g., office maintenance) and non-revenue-generating areas (e.g., public relations). Following Leone and Van Horn (2005), I measure accrual-based earnings management (AEM) using discretionary accruals. I find that hospitals decrease RAM and AEM when they overbill, but increase AEM when they engage in RAM.

Finally, I examine under what circumstances hospitals resort to overbilling instead of RAM or AEM. Prior accounting research argues that RAM and AEM are constrained in situations of high competition, poor financial health, and previous extensive use of AEM. In 
contrast to prior research showing that firms use AEM when RAM is constrained and vice versa (e.g., Zang, 2012), I find that hospitals use overbilling instead of AEM or RAM when either of the latter strategies is constrained. In particular, when RAM is constrained due to hospitals' weaker competitive status or financial distress, hospitals increase overbilling but not AEM. When AEM is constrained by prior accounting choices, I find that hospital managers resort to overbilling instead of RAM. These findings are most pronounced in DRG family 79, i.e., the family that offers the highest financial gains from overbilling, suggesting that overbilling is the preferred manipulation tool of hospitals when AEM and RAM are constrained, and that overbilling reduces hospitals use of AEM and RAM.

Despite its benefits, overbilling is likely to be constrained by hospitals' operations. For instance, only hospitals that treat a large number of patients who fall within these three DRG families can generate additional revenues via overbilling sufficient to substantially affect reported performance. In addition, hospitals that are part of a multihospital system typically use more sophisticated information technology, share information regarding billing, medical, and financial performance, and align the product mix of member hospitals (e.g., Dranove \& Shanley, 1995). These hospitals enjoy substantial expertise and economies of scale arising from centralized coding efforts that can also enable higher overbilling (Dafny \& Dranove, 2009). Consequently, I examine whether hospitals that treat fewer patients in these three DRG families or are not part of a hospital system are more constrained by their operations from engaging in overbilling. I find that hospitals subject to such constraints are less likely to practice overbilling and cut discretionary expenditures instead. These results suggest that hospitals replace overbilling with a manipulation tool that also has a cash-flow effect. 
Rigorous regulatory and market oversight is also likely to constrain overbilling, which can be very costly for hospitals when detected and deemed fraudulent (Becker, Kessler, \& McClellan, 2005). For instance, in 2006, Tenet, a for-profit hospital chain, paid $\$ 900$ million to resolve claims it engaged in fraudulent billing and sold 11 hospitals to finance the settlement (Walsh, 2007). I focus on two types of hospitals subject to more-intense oversight. First, publicly listed hospitals could engage in less overbilling than their non-listed peers, as they are subject to stricter regulatory oversight by more regulatory agencies such as the Securities and Exchange Commission (SEC). ${ }^{2}$ Publicly listed hospitals are also subject to more-extensive market monitoring, which can further constrain overbilling. If managers expect other market participants to impose costs on the hospital in case overbilling is detected, they could overbill less than their non-listed peers. Such costs imposed by the market can be substantial, as the Tenet example illustrates. After the public revelation of its fraudulent billing in October 2002, Tenet's stock price lost about two-thirds of its value within a couple of weeks (Abelson, 2002). I find that publicly listed hospitals overbill less but engage in more AEM and RAM than their non-listed peers, suggesting that overbilling could be more constrained among publicly listed hospitals. Second, oversight is likely to be higher for hospitals that have been prosecuted for overbilling, i.e., they are subject to more scrutiny from regulators as well as other stakeholders regarding their billing choices (Becker et al., 2005). I find that prosecuted hospitals subsequently engage in less overbilling, instead cutting discretionary expenditures as well as managing accruals. These findings show that the substitution of one manipulation tool for another works both ways, i.e., when overbilling is constrained, hospitals use RAM and AEM instead.

\footnotetext{
${ }^{2}$ For instance, in 2007, the SEC charged Tenet with fraudulent billing and in 2013 it charged the largest hospital in Miami with fraudulent billing (SEC, 2007, 2013).
} 
My findings contribute to the accounting literature in the following ways. First, I provide a comprehensive picture of hospitals' earnings management choices by documenting that overbilling decreases hospitals' use of RAM and AEM. Given the growing interest in understanding hospitals' earnings management decisions (e.g., Eldenburg et al., 2011; Hoerger, 1991; Leone \& Van Horn, 2005; Vansant, 2015) and the economic importance of the healthcare sector, my findings have important implications, because they suggest that overbilling is systematically used by hospitals to manage earnings. Second, I explore constraints associated with each manipulation tool in the healthcare industry. The findings that hospitals prefer overbilling when AEM or RAM is constrained, and that hospitals use RAM or AEM when overbilling is constrained, enhance our understanding of managers' choices of manipulation tools and demonstrate that such choices can differ across industries. The results of this study should also be of interest to stakeholders in the healthcare sector. For instance, for hospital auditors and regulators the study highlights a set of operational conditions potentially associated with overbilling. One caveat of this study is that the findings pertain to the period before new DRGs were introduced. Future research could examine the role of overbilling in hospitals' earnings management choices under the new coding scheme and point out potential differences.

Section 2 explains overbilling and summarizes prior earnings management literature. Section 3 develops the hypotheses, Section 4 presents the data and methodology, and Section 5 provides the empirical results. Section 6 concludes.

\section{Overbilling and Prior Earnings Management Literature}

Overbilling is possible because hospitals can use discretion in coding patients into DRGs, including those that yield higher reimbursement (see also Heese et al., 2016 and Silverman \& Skinner, 2004). The DRG assigned by hospitals' medical coders at the time of discharge becomes 
the basis for reimbursement. Although this assignment is based on patients' medical records, there is latitude in assigning patients to one DRG versus another. For instance, in the case of respiratory ailments (i.e., DRG family 79), the judgment involved in diagnosing pneumonia as well as complicating factors facilitates this latitude. The diagnosis of pneumonia relies on symptoms (e.g., fever, cough and sputum production) in conjunction with X-rays of the lungs and sputum samples. However, diagnosis is often made more difficult when the sputum sample or Xray proves inconclusive, allowing hospitals to move patients into higher-paying DRGs. Second, the diagnosis of complicating factors involves judgment. For example, to assign a patient to DRG 79 (respiratory infections with complications) instead of DRG 80 (respiratory infections without complications), the hospital has to add to the medical record a complicating factor such as anemia, asthma, diabetes, depression, hypertension, ulcer, or others. As the diagnosis of these factors requires a judgment rather than material evidence, hospitals can move patients into DRG 79 , which results in a revenue gain of $\$ 3,811$ without any corresponding cost.

Hospital management can facilitate overbilling by encouraging medical coders to overbill (Dafny, 2005). Overbilling is a long-known problem and estimated to have increased over time despite ongoing efforts to prevent it. For instance, healthcare regulators regularly conduct audits of medical records (CMS, 2004, 2013) and prosecute hospitals for fraudulent billing under the False Claims Act (FCA), which can lead to huge settlements (Congress, 1863, 1986).

A few studies have identified hospitals' motives for overbilling. Soderstrom (1993) shows that hospitals in poor financial condition and/or with higher marginal costs overbill more. Silverman and Skinner (2004) provide evidence that for-profit hospitals overbill more than nonprofit hospitals, while Dafny and Dranove (2009) show that management teams who fail to 
exploit overbilling potential are vulnerable to replacement. Further, Heese et al. (2016) find that nonprofit hospitals overbill to fund the provision of charity care and medical education.

Although overbilling is ubiquitous, it has rarely been studied in the accounting literature or linked to other manipulation tools. In contrast, there is a huge literature in accounting on earnings management via accruals (Healy \& Wahlen, 1999; Schipper, 1989) and real activities (Roychowdhury, 2006; Vorst, 2016). Recently, studies have begun to acknowledge that managers use multiple earnings management techniques simultaneously and choose among them depending on the constraints associated with each strategy. For instance, Graham, Harvey, and Rajgopal (2005) document that managers prefer RAM over AEM, and Zang (2012) provides evidence of the trade-off decisions between RAM and AEM. With respect to hospitals, prior research shows that for-profit hospitals' motives to manage earnings are similar to those of other for-profit industries (Eldenburg, Hermalin, Weisbach, \& Wosinska, 2004). For instance, bonus payments (Roomkin \& Weisbrod, 1999), career concerns (Dafny \& Dranove, 2009), and pressure from stakeholders (Eldenburg et al., 2004) drive earnings management in these organizations. Perhaps not surprisingly, hospitals have also been found to manage their earnings via AEM and RAM (e.g., Eldenburg et al., 2011; Hoerger, 1991; Leone \& Van Horn, 2005; Vansant, 2015).

\section{Hypotheses}

\subsection{Substitution between Manipulation Strategies}

Overbilling has advantages over managing accruals and cutting discretionary expenditures, because hospitals can increase revenues without altering operations, affecting costs, or having to reverse it. Thus, I propose that overbilling reduces hospital managers' use of accrualbased or real activities earnings management, as summarized in the following hypothesis:

H1: Real activities manipulation (accrual-based earnings management) and overbilling are substitutes to manage earnings. 


\subsection{Variation in Hospitals' Constraints across Manipulation Strategies}

Hospitals' use of these manipulation strategies is likely to be driven by the constraints associated with each strategy. Below I discuss these constraints to develop hypotheses regarding the circumstances under which hospitals prefer one manipulation tool over another.

\subsubsection{Constraints associated with real activities manipulation}

Prior research (e.g., Zang, 2012) has argued that RAM is constrained in situations of high competition and financial distress because it involves changing firms' operations. For instance, financial distress constrains RAM because for organizations that are in a "negative tailspin" (Graham et al., 2005), the marginal costs of changing operations are likely to be especially high. In line with that argument, Zang (2012) finds that firms are more likely to apply AEM instead of RAM in situations of intense competition and distress.

However, AEM can also be constrained by competition and distress. Marciukaityte and Park (2009) argue that in a competitive environment firms could hesitate to engage in AEM, since they will be harshly punished by the market if the manipulation comes to light. In situations of distress, AEM is constrained because auditors prefer conservative accounting choices to protect themselves against future litigation (DeFond \& Subramanyam, 1998).

As overbilling allows hospitals to manage performance without changing operations and provides resources to reduce the negative impact of competition or distress, I argue that hospitals operating in a more competitive market or under distress are less likely to cut expenditures than they are to overbill. This argument is summarized in the following hypothesis:

$\mathrm{H} 2$ : Hospitals that are in poor financial health or operating in a competitive market are more likely to overbill than to cut discretionary expenditures. 


\subsubsection{Constraints associated with accrual-based earnings management}

Accrual-based earnings management is constrained by prior years' accounting choices as accruals have to reverse (Baber, Kang, \& Li, 2011; Barton \& Simko, 2002). ${ }^{3}$ Consistent with this argument, studies find that managers apply more RAM if prior years' accounting choices constrain AEM (Cohen, Dey, \& Lys, 2008; Zang, 2012). I predict that instead of using more RAM, managers switch to overbilling when managing accruals is constrained by prior years' accounting choices, as overbilling does not require changing operations. I state the following hypothesis:

H3: Hospitals with low accounting flexibility are more likely to overbill than to manage accruals.

\subsubsection{Constraints associated with overbilling}

While overbilling has many advantages over RAM and AEM, it is constrained by hospitals' operations and regulatory as well as market oversight. Two operational features in particular can affect hospitals' likelihood to overbill: the number of patients treated within each DRG family and membership in a multihospital system. Hospitals that treat higher numbers of patients within each DRG family can generate greater revenues from overbilling, more substantially affecting performance. Membership in a multihospital system can also enable overbilling, as such hospitals typically use more sophisticated information technology, share information regarding billing, medical, and financial performance, and align their product mix with those of other member hospitals (Bazzoli, Chan, Shortell, \& D'Aunno, 2000; Burke, Wang,

\footnotetext{
${ }^{3}$ While prior studies (e.g., Zang, 2012) also focus on the presence of high-quality auditors as an AEM constraint, this constraint is very difficult to explore in my setting, as almost all hospitals are audited by Big 4 auditors, and California hospitals are subject to an additional government audit of their financial statements (OSHPD, 2011), making it difficult to disentangle the role of the hospital from that of the government auditor.
} 
Wan, \& Diana, 2002; Dranove \& Shanley, 1995), effectively disguising overbilling (Dafny \& Dranove, 2009).

Hospitals that treat fewer patients in these DRG families or are not part of a hospital system might choose to use AEM or RAM instead. Unlike AEM, RAM has a cash-flow effect by decreasing costs and holding revenues constant, making it a more-attractive substitute for overbilling. Thus, I argue that hospitals subject to these two operational constraints are less likely to overbill than to engage in real activities manipulation, as stated in the following hypothesis:

H4a: Hospitals with few inpatients within DRG families 79, 144, and 296 or that are not part of a multihospital system are less likely to overbill than to cut discretionary expenditures.

Overbilling is also constrained by regulatory and market oversight. First, publicly listed hospitals could engage in less overbilling than non-listed hospitals, as they are subject to stricter oversight by regulatory agencies such as the SEC. Publicly listed hospitals are also subject to closer market monitoring, further constraining overbilling. Second, oversight from regulators as well as other stakeholders is likely to be more intense for hospitals that have been prosecuted for overbilling (Becker et al., 2005). I argue that, instead of overbilling, both types of hospitals apply RAM, which offers a direct cash-flow effect, leading to the following hypothesis:

H4b: Publicly listed hospitals or hospitals that have been prosecuted for overbilling are less likely to overbill than to cut discretionary expenditures.

\section{Data and Methodology}

\subsection{Data}

I use a sample of general acute-care for-profit hospitals in California to test the hypotheses. I focus on for-profit hospitals to make the results more comparable to prior research 
on earnings management of for-profits in other industries. I choose the 1996-2007 period, as patient-level data are not available before 1996 and new DRGs were introduced after 2007, making it difficult to compare overbilling across DRG regimes (CMS, 2010). I exclude specialty hospitals because of their differences in reimbursements, production functions, and patient mixes. My final sample consists of 115 hospitals and 902 hospital-year observations.

\subsection{Methodology}

\subsubsection{Measurement of overbilling}

I focus on three DRG families prone to overbilling: "General respiratory ailments" (DRG family 79), "circulatory system disorders" (DRG family 144), and "diabetes and metabolic disorders" (DRG family 296). Table 1, panel A and B (adopted from Heese et al., 2016) show the financial gains from overbilling in these DRG families. Hospitals in my sample have on average 652 discharges per year for patients within these DRG families, representing about $11.2 \%$ of all hospital discharges (see Table 1, panel C).

- Table 1 here -

As a first step, I estimate a hospital's normal billing. Similar to Heese et al. (2016), I regress the percentage of patients coded into the highest-paying DRG within each family on variables associated with normal billing (e.g., the patients' health status), but not any earnings management motives. This research design is based on studies conducted by government agencies (e.g., GAO, 2000; OIG, 1998), which show that hospitals inappropriately coded patients into the highest-paying DRGs within these DRG families. In particular, I run the following crosssectional regression for every year $t$ separately for each of the three DRG families: 


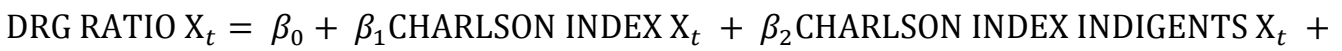
$\beta_{3}$ MORTALITY RATE X $_{t}+\beta_{4} \%$ MEDICARE $_{t}+\beta_{5} \%$ CHARITY CARE $_{t-1}+\beta_{6} \%$ RESIDENTS $_{t-1}+\beta_{7}$ RURAL $_{t}+$ $\beta_{8} \mathrm{CMI}_{t}+e_{t}$

DRG RATIO X is either DRG Ratio 79, DRG Ratio 144, or DRG Ratio 296, and is the number of patients coded into the Top DRG divided by the sum of patients discharged from all DRGs within a family. Following Heese et al. (2016), I control for the health status of patients within these families as well as hospital characteristics that reflect differences in patients' health status and patient mix. To control for patients' health status, I include the CHARLSON INDEX X and MORTALITY RATE X. The Charlson Index captures the weighted average of a patient's health status within each DRG family and is a widely applied measure for a patient's health status (Charlson, Pompei, Ales, \& MacKenzie, 1987). ${ }^{4}$ The more severely ill patients are (i.e., the higher the Index) the more likely it is to code patients in the top DRG. If the documentation of the patient's health status is adjusted by hospitals to justify the coding choice, controlling for the Charlson Index leads to an underestimation of overbilling. The mortality rate reflects the proportion of patients that died within a specific DRG family while staying at the hospital. I also include a separate Charlson Index for the indigent patient population within each DRG family (CHARLSON INDEX INDIGENTS X) to control for the possibility that indigents are more severely ill. To control for other factors that reflect differences in the patient mix, I include the hospital's Case Mix Index (CMI), the percentage of Medicare patients (\%MEDICARE) treated by the hospital measured in patient days, hospital location in a rural area (RURAL), and the hospital's provision of charity care and medical education. \%CHARITY CARE $_{t-1}$ is the level of charity care at the beginning of the year scaled by lagged assets and \% RESIDENTS t-l $_{\text {is }}$ the share

\footnotetext{
${ }^{4}$ The Index assigns weights $(1,2,3,6)$ based on comorbidity (e.g., weight 1 for diabetes, weight 6 for metastatic solid tumor) and age ( 0 to 5 ; where 1 point is assigned for each decade starting at 50, e.g., 40 to $49=0 ; 50$ to $59=1$ ). The weighting is based on the number of patients per DRG within each family.
} 
of residents trained per inpatient bed at the beginning of the year. ${ }^{5}$ The residuals from equation 1 represent an estimate of overbilling as they contain the abnormal level of billing for each of the three DRG families (denoted OVERBILLING X, where X is either 79, 144, or 296).

\subsubsection{Measurement of real activities manipulation}

Following Eldenburg et al. (2011), I examine cutting discretionary expenditures in (1) non-revenue generating activities such as advertising expenditures, general services or public relations, denoted EXP, and (2) non-operating activities such as maintenance of office space, denoted NOCC. ${ }^{6}$ I follow Roychowdhury (2006) and estimate the normal level of non-revenue generating activities and non-operating activities using the following equations for every year $t$ :

$$
\begin{aligned}
& \operatorname{EXP}_{t}=\beta_{0}+\beta_{1}\left(1 / \mathrm{A}_{t-1}\right)+\beta_{2}\left(\mathrm{~S}_{t-1} / \mathrm{A}_{t-1}\right)+e_{t} \\
& \operatorname{NOCC}_{t}=\beta_{0}+\beta_{1}\left(1 / \mathrm{A}_{t-1}\right)+\beta_{2}\left(\mathrm{~S}_{t-1} / \mathrm{A}_{t-1}\right)+e_{t}
\end{aligned}
$$

$\mathrm{A}_{t-1}$ is total assets in year $t-1$; and $\mathrm{S}_{t-1}$ is net patient revenues in year $t-1$. The abnormal level of the expenditures is measured as the estimated residuals from these regressions. I multiply the residuals by -1 such that higher values indicate greater cuts to increase earnings. To arrive at the measure for real activities manipulation, denoted RAM, I take the sum of the residuals.

\subsubsection{Measurement of accrual-based earnings management}

I use discretionary accruals to proxy for AEM. Similar to Leone and Van Horn (2005), I estimate the latter using the following Jones (1991) model for every year $t$ :

\footnotetext{
${ }^{5}$ Charity care is the difference between established charges for services rendered and the amount paid by or on behalf of the patient, if any. The higher this share, the more costs the hospital faces from treating patients that cannot — or only partly_ pay their bills. As an alternative measure, I also use \%INDIGENTS $t_{t-1}$, which is defined as the percentage of indigent patients for whose treatment the hospital received no compensation to the hospital's total patient population (measured in patient days). The inferences are unaffected (untabulated).

${ }^{6} \mathrm{EXP}$ is the sum of total research expenditures, total administrative services, total general services, and total education expenditures, and NOCC is the sum of total maintenance expenditures, physicians' offices and other rentals expenditures, total office building expenditures, child care services expenditures, family housing expenditures, retail operations expenditures, and other non-operating expenditures.
} 
$\operatorname{ACCRUALS}_{t} / \mathrm{A}_{t-1}=\beta_{0}+\beta_{1}\left(1 / \mathrm{A}_{t-1}\right)+\beta_{2} \frac{\Delta \mathrm{S}_{t}}{\mathrm{~A}_{t-1}}+\beta_{3} \frac{\mathrm{PPE}_{t}}{\mathrm{~A}_{t-1}}+e_{t}$

ACCRUALS equals noncash working capital accruals as in Allen et al. (2013) and

Richardson et al. (2005) in year $t ; \Delta \mathrm{S}_{t}$ is change in net patient revenue; and $\mathrm{PPE}_{t}$ is the gross property, plant, and equipment. ${ }^{7}$ The estimated residuals, denoted AEM, are my proxy for AEM. ${ }^{8}$

\subsubsection{Test of the hypotheses}

Following Zang (2012), I estimate the following equations to test H1-H4:

$$
\begin{aligned}
& \text { OVERBILLING X } \beta_{t}=\beta_{0}+\sum_{k} \beta_{1, k} \text { CONSTRAINTS OF OVERBILLING }_{k, t}+\sum_{l} \beta_{2, l} \text { CONSTRAINTS OF RAM }_{l, t}+ \\
& \sum_{m} \beta_{3, m} \text { CONSTRAINTS OF AEM }_{m, t}+\sum_{n} \beta_{4, n} \operatorname{CONTROLS}_{n, t}+u_{t} \\
& \text { RAM }_{t}=\gamma_{0}+\sum_{k} \gamma_{1, k} \text { CONSTRAINTS OF RAM }_{k, t}+\sum_{l} \gamma_{2, l} \operatorname{CONSTRAINTS~OF~OVERBILLING~}_{l, t}+ \\
& \sum_{m} \gamma_{3, m} \text { CONSTRAINTS OF AEM }_{m, t}+\sum_{n} \gamma_{4, n} \operatorname{CONTROLS}_{n, t}+v_{t} \\
& \mathrm{AEM}_{t}=\delta_{0}+\sum_{k} \delta_{1, k} \text { CONSTRAINTS OF AEM }_{k, t}+\sum_{l} \delta_{2, l} \operatorname{CONSTRAINTS~OF~RAM~}_{l, t}+ \\
& \sum_{m} \delta_{3, m} \text { CONSTRAINTS OF OVERBILLING }_{m, t}+\delta_{4} \text { OVERBILLING X }_{t}+\delta_{5} \operatorname{RAM}_{t}+\sum_{n} \delta_{6, n} \operatorname{CONTROLS~}_{n, t}+ \\
& w_{t}
\end{aligned}
$$

H1 predicts that overbilling reduces the use of RAM and AEM. Because overbilling and RAM are conducted during the fiscal year, throughout the year hospitals can apply overbilling as a substitute for RAM conditional on other confounding variables. To investigate this, I use two different approaches. First, I include the realized levels of overbilling in the RAM model, i.e., equation 6. Second, I follow Arora (1996) and Grabner and Moers (2013) and estimate the conditional correlation of overbilling and real activities manipulation, i.e., the correlation of the residuals from equation 5 and $6\left(u_{t}\right.$ and $\left.v_{t}\right)$. Using both approaches, I expect the association to be negative. At fiscal year-end, overbilling and RAM are realized, after which managers can still

\footnotetext{
$7 \mathrm{TA}_{t}=\left(\Delta \mathrm{CA}_{t}-\Delta \mathrm{CL}_{t}-\Delta \mathrm{CASH}_{t}+\Delta \mathrm{STD}_{t}\right) / \mathrm{A}_{t-1}$ where $\Delta \mathrm{CA}$ is change in current assets; $\Delta \mathrm{CL}$ is change in current liabilities; $\triangle \mathrm{CASH}$ is change in cash and cash equivalents; $\Delta \mathrm{STD}_{\mathrm{t}}$ is change in debt included in current liabilities; and $\mathrm{A}_{t-1}$ is total assets in year $t-1$.

${ }^{8}$ Alternatively, I also estimate overbilling, RAM, and AEM using a one-year-ahead prediction model instead of a contemporaneous prediction model. Results from this alternative model are directionally consistent with those using contemporaneous residuals (untabulated).
} 
adjust the level of AEM. To test whether managers adjust AEM based on the realized level of overbilling and RAM, I examine whether $\delta_{4}$ and $\delta_{5}$ in equation 7 are negative. I also replace $\delta_{4}$ and $\delta_{5}$ in equation 7 with the unexpected levels of overbilling and RAM (see Zang, 2012), which are the residuals from equations 5 and 6 (Zang, 2012).

$\mathrm{H} 2-\mathrm{H} 4$ predict that the choice between manipulation tools depends on the constraints associated with each strategy (I define the measurement of these constraints, denoted CONSTRAINTS OF OVERBILLING, RAM and AEM in equations 5 to 7 , in the following three subsections). If one strategy is constrained, I predict that hospitals will increase their use of at least one of the other two strategies. All regressions include year fixed effects, are estimated using OLS, and standard errors are clustered by hospital. ${ }^{9}$

\subsubsection{Constraints of real activities manipulation}

I use the Herfindahl-Hirshman Index at the beginning of the year $\left(\mathrm{HHI}_{t-1}\right)$ to measure the competitive pressures hospitals face in their local market. I define counties as local markets and calculate the Index using discharges (e.g., Dranove, Shanley, \& White, 1993). To measure financial distress, I create an indicator variable, denoted DISTRESS $_{t-1}$, equal to one if the Altman Z-Score (Altman, 1968) at the beginning of the year is smaller than 3. Altman (1968) defines firms with a Z-Score below 3 as being in the gray area or financially distressed. I create the Z$\mathrm{SCORE}_{t-1}$ by replacing the market with the book value of equity.

\subsubsection{Constraints of accrual-based earnings management}

\footnotetext{
${ }^{9}$ As an alternative estimation technique, I use seemingly unrelated regressions (which takes into consideration the correlation in the error terms across equations), because the earnings management strategies are associated. The inferences are unaffected (untabulated). In addition, recent research by Chen, Hribar, and Melessa (2016) suggests that using a two-step approach to measure overbilling (i.e., I estimate overbilling in the first step and use the residuals from that step as the overbilling measure in the second step) can produce biased results when the regressors from the first step are correlated with regressors in the second step. As a solution, Chen et al. (2016) suggest estimating all coefficients in one step. The results from such single-step model are consistent with those presented in Table 5 (untabulated).
} 
Following Barton and Simko (2002), I use net operating assets (i.e., equity less cash and marketable securities plus total debt) at the beginning of the year divided by lagged revenues $\left(\mathrm{NOA}_{t-1}\right)$ to proxy for hospitals' accounting flexibility. Because of the articulation between the income statement and the balance sheet, AEM reflected in past earnings is also reflected in net assets; hence the latter are overstated when firms use AEM in previous periods (Zang, 2012).

\subsubsection{Constraints of overbilling}

I use the natural logarithm of the discharges per DRG family (LOG DRG $\mathrm{X}$ DISCHARGES, where $X$ is either DRG family 79,144 , or 296) to measure the size of the patient population. SYSTEM equals one if the hospital is a member of a multihospital system as per the California Office of Statewide Health Planning and Development (OSHPD) (Krishnan \& Yetman, 2011). To identify hospitals that are prosecuted for overbilling, I collect data from False Claims Act settlements (Heese et al., 2016), and define the prosecution period as the years following the last violation year until two years after the settlement year (PROSECUTION). ${ }^{10}$ PUBLIC is one if a hospital is part of a publicly listed hospital system.

\subsubsection{Controls}

I include several controls. First, I include BENCHMARK, which is one for hospitals that have just met the zero-earnings benchmark, identified as hospitals with ROA in the interval $(0$, 0.04) (Degeorge, Patel, \& Zeckhauser, 1999). Next, I create an incentive compensation variable

\footnotetext{
${ }^{10}$ Following Heese et al. (2016), I obtain information on FCA settlements from several sources. First, the law firm Fried, Frank, Harris, Shriver \& Jacobson, LLP provides a list of settlements for the period 1993-2005 at http://www.friedfrank.com/files/QTam/SettlementsArchive.pdf. Second, the Taxpayers Against Fraud Education Fund lists settlements as of 2004 at http://www.taf.org/resource/fca/statistics. Third, the OIG lists settlements as of 2003 at http://oig.hhs.gov/reports-and-publications/archives/enforcement/false claims archive.asp. The Health Care Fraud and Abuse Control Program Reports (available at https://oig.hhs.gov/reports-and-publications/hcfac/index.asp) list FCA settlements as of 1997. In robustness tests (untabulated), I use alternative specifications of PROSECUTION. First, I use only the period following the last violation year until the settlement year as prosecution period and, second, I include all years following the settlement year. The results are robust to these alternative specifications.
} 
(P4P) by regressing the change in the log of managerial compensation on the change in ROA and the standard deviation of ROA over three years (Eldenburg et al., 2011). ${ }^{11} \mathrm{P} 4 \mathrm{P}$ is one for hospitals that have a positive coefficient on ROA. Further, I include OCCUPANCY RATE to control for hospital efficiency, defined as the number of patient days scaled by beds times 365 (Eldenburg \& Krishnan, 2008). I include ROA to control for hospital performance, and the natural logarithm of total assets (LOG ASSETS) to control for hospital size. To control for monitoring effectiveness, I include the natural logarithm of the number of board members (LOG BOARD SIZE). Appendix A provides an overview of the variables.

\subsection{Descriptive Statistics}

Descriptive statistics are summarized in Table 2. Mean (median) total assets are $\$ 62$ million ( $\$ 35$ million) and the mean (median) number of discharges is 5,816 $(4,910)$. The mean (median) HHI is $0.10(0.06)$, indicating that the average hospital faces high competition. About $25 \%$ of all hospital-year observations are in the gray area as their Z-Score is smaller than 3. On average, about half of the hospitals belong to a system, and about 66 percent are publicly listed. The descriptive statistics show that about 4 percent of all hospitals are prosecuted for overbilling.

Table 2, panel B presents the Pearson and Spearman correlations of the variables. I find a positive and significant correlation between the size of the patient populations and LOG ASSETS (Pearson correlation of 0.50), LOG ASSETS and PUBLIC (Pearson correlation of 0.48), LOG ASSETS and SYSTEM (Pearson correlation of 0.48), and LOG ASSETS and LOG BOARD SIZE (Pearson correlation of 0.43 ), indicating that larger hospitals are more likely to treat

\footnotetext{
${ }^{11}$ As the dataset does not include compensation details for individuals, I use the annual sum of salaries, bonuses, and benefits of the top hospital administrators including the Chief Executive Officer, Medical Director, Nursing Director, and their assistants, and scale this sum by the number of full-time equivalent employees (FTEs) in the top administrative team to obtain my measure of compensation (Eldenburg et al., 2011). All variables are panel-specific random parameters.
} 
patients in the three DRG families, be publicly listed, be members of a hospital system, and have larger boards than smaller hospitals.

\section{Results}

- Table 2 here -

\subsection{Abnormal Levels of Billing, Real Activities and Accruals}

Table 3, panel A shows the results of estimating the normal levels of billing, non-revenue generating and non-operating activities, and working capital accruals to determine abnormal levels of billing, real activities and accruals. On average, each yearly regression contains more than 75 hospital observations.

The results for estimating the normal levels of billing are consistent with Heese et al. (2016). For instance, the mean coefficients on the mortality rate are positive and significant in all three DRG families. In addition, the coefficients on charity care and the provision of medical education are positive and significant in two out of three DRG families. Furthermore, the proxies for hospitals' patient mix, i.e., the CMI and \%MEDICARE are positive and significant in at least one out of three models. The models also show that rural hospitals have relatively fewer patients assigned to the highest-paying DRGs. The mean adjusted $\mathrm{R}^{2}$ for the three overbilling estimation models range from 31.8 percent for DRG family 296 to 37.3 percent for DRG family 79, indicating that the models explain about one third of the variation of the percentage of patients assigned to the highest-paying DRGs. Similar to AEM and RAM estimation models, I cannot ensure that each case of abnormal billing is actually strategic over- or underbilling. Underbilling (as proxied by negative residuals) can occur if hospitals face constraints to overbill and are therefore especially careful in their coding choices. $\mathrm{H} 4$ focuses on such constraints and identifies 
hospitals (e.g., publicly listed hospitals) or specific situations in which hospitals choose to underbill (e.g., after being prosecuted for overbilling). ${ }^{12}$

The estimations of the normal levels of non-revenue generating and non-operating activities, and working capital accruals, are similar to those found in prior research (Roychowdhury, 2006; Zang, 2012). The mean adjusted $\mathrm{R}^{2}$ ranges from $5.5 \%$ for equation 3 , to 12.1 percent for equation 4 , to 73.6 percent for equation 2 . The explanatory power of these models is slightly lower than in prior studies that focus on for-profits in other industries, suggesting that these models are less powerful in explaining RAM and AEM in the healthcare sector; perhaps because this industry is highly regulated, limiting the use of RAM and AEM.

Table 3, panel B shows the summary statistics for the earnings management measures. All measures have a mean close to zero. The median level of overbilling ranges from $-1.3 \%$ for DRG family 144 to $1.8 \%$ for DRG family 296 . These descriptives are in line with the descriptives of firm characteristics that constrain overbilling. Specifically, given that about $66 \%$ of all hospitals are publicly listed and about half of the hospitals do not belong to a system (see Table 2, panel A), it is perhaps not surprising that the median level of overbilling in the two highest-paying DRG families is negative. In fact, if publicly listed hospitals and hospitals prosecuted for overbilling are excluded from the descriptives, the median level of overbilling in DRG families 79 and 144 increases to $1.6 \%$ and $0.3 \%$, respectively. I also report the Pearson and Spearman correlations among the variables in Table 3, panel $\mathrm{C}$. The three overbilling measures are positively correlated with each other, suggesting that, if hospitals overbill, they do it across all three families. For both Pearson and Spearman correlations there is a positive correlation between

\footnotetext{
${ }^{12}$ In untabulated robustness tests, I find qualitatively similar results to those reported in Table 5 when I run the tests presented in Table 5 on the subset of hospitals that overbill (as defined by positive residuals). Hospitals that underbill (as defined by negative residuals) use more AEM and RAM.
} 
RAM and AEM, and a negative correlation between all three overbilling measures and RAM, and between overbilling and AEM. These correlations provide some preliminary evidence in support of H1 that firms apply RAM and AEM as complements but apply overbilling as a substitute for the other two strategies. Finally, Table 3, panel D, reports the correlations between overbilling, RAM, and AEM in year $t$ and year $t+1$. Overbilling in year $t$ is strongly correlated with overbilling in year $t+1$, showing that hospitals do not have to reverse such behavior and highlighting the persistence of overbilling. In contrast, AEM in year $t$ is negatively correlated with AEM in year $t+1$, consistent with accruals having to reverse.

- Table 3 here -

\subsection{Validation of Overbilling Measures}

I run three tests to validate the overbilling measures. First, I examine the relation between these measures and hospitals' cash collections, i.e., operating cash flows divided by beginningof-year total assets, because overbilling leads to increased cash collections. As reported in Table 4, I find that overbilling in DRG families 79 and 144 is associated with higher operating cash flows. The results also appear economically significant. For instance, an increase in overbilling 79 (144) by one standard deviation is estimated to translate into a 6.2 (2.4) percentage point increase in operating cash flows. Second, to more directly examine whether hospitals use overbilling to manage their earnings, I examine the relation between the overbilling measures and hospitals' M-Scores. The M-Score (Beneish, 1999) is a proxy to identify firms likely to manipulate their earnings. ${ }^{13}$ As reported in Table 4, I find that overbilling in the two highest-

\footnotetext{
${ }^{13}$ The M-Score is calculated as follows: M-SCORE $=-4.84+0.920(\mathrm{DSR})+0.528(\mathrm{GMI})+0.404(\mathrm{AQI})+$ 0.892 (SGI) +0.115 (DEPI) -0.172 (SGAI) +4.679 (Accruals) -0.327 (LEVI). DSR $=\left(\right.$ Receivables $_{t} /$ Net Patient Revenues $\left._{t}\right) /\left(\right.$ Receivables $_{t-1} /$ Net Patient Revenues $\left.{ }_{t-1}\right) ; \mathrm{GMI}=$ Gross Margin $_{t-1} /$ Gross Margin $_{t} ; \mathrm{AQI}=\left[1-\left(\mathrm{PPE}_{t}+\right.\right.$ Current Assets $t) /$ Total Assets $\left.t_{t}\right] /\left[1-\left(\right.\right.$ PPE $_{t-1}+$ Current Assets $\left._{t-1}\right) /$ Total Assets $\left._{t-1}\right] ;$ SGI $=$ Net Patient Revenues $t_{t} /$ Net Patient Revenues $_{t-1} ;$ DEPI $=\left[\right.$ Depreciation $_{t-1} /\left(\right.$ Depreciation $_{t-1}+$ PPE $\left.\left._{t-l}\right)\right] /\left[\right.$ Depreciation $_{t} /\left(\right.$ Depreciation $\left.\left._{t}+\mathrm{PPE}_{t}\right)\right]$;
} 
paying DRG families is positively and significantly associated with the M-Score, suggesting that overbilling is used to manage earnings. In these tests, I control for ROA, Z-Score, total assets, board size, rural hospital location, and system membership.

\subsection{Results for $\mathrm{HI}$}

- Table 4 here -

H1 states that hospitals apply overbilling and RAM or AEM as substitutes. Table 5 presents the results of estimating equations 5-7 and Table 6, panel A shows the association between overbilling and RAM. Using both realized levels of overbilling as well as conditional correlations of the residuals, I find a negative association between these earnings management strategies. In particular, using the realized levels of overbilling (see Column 1 in Table 6, panel A), I find that the coefficients on overbilling in all three DRG families are negative and significant at $p<0.10$. Using conditional correlations (see Column 2 in Table 6, panel A), I find a negative and significant correlation at $p<0.10$ for overbilling in DRG families 79 and 144 . In sum, these results suggest that managers use RAM and overbilling as substitutes.

The results in Table 6, panel B, provide insights into the relation between the levels of realized as well as unexpected overbilling and RAM on the level of AEM. In particular, the coefficients on realized (Column 1) as well as unexpected (Column 2) overbilling 79 and 144 are negative and significant, indicating that overbilling in these DRG families negatively affects the level of AEM. In contrast, hospitals also use more AEM if they apply RAM, as suggested by the positive and significant coefficient on realized (Column 1) as well as unexpected (Column 2) RAM. Overall, these findings support $\mathrm{H} 1$ and suggest that hospital managers use overbilling as a substitute for AEM and RAM, while AEM and RAM are applied as complements to each other.

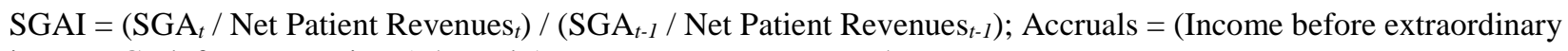
items $_{t}-$ Cash from operations $_{t}$ ) $/$ Total Assets $_{t}$, LEVI $=$ Leverage $_{t} /$ Leverage $_{t-l}$. 


\subsection{Results for $\mathrm{H} 2-\mathrm{H} 4$}

Table 5 presents the results of estimating equations 5-7 to test $\mathrm{H} 2-\mathrm{H} 4$, providing evidence on managers' choices based on the constraints associated with each strategy, i.e., H2-H4. In the RAM equation in Column 4, the coefficient on $\mathrm{HHI}_{t-1}$ is positive and significant and the coefficient on DISTRESS t-l $_{1}$ is negative and significant, indicating that hospitals engage in less RAM if they face intense competition or are financially unhealthy (Zang, 2012). Instead, the coefficient on $\mathrm{HHI}_{t-1}$ is negative and significant at $p<0.10$ in Columns 1 and 3 and the coefficient on DISTRESS $t_{t-1}$ is positive and significant at $p<0.10$ in Column 1, indicating that hospitals overbill most in DRG families 79 and 296. In addition, the results show that hospitals engage in higher levels of AEM when they are financially less healthy, as indicated by the positive and significant coefficient on DISTRESS $\mathrm{t}_{t-1}$ in Column 5. These findings are consistent with $\mathrm{H} 2$, as they indicate that managers reduce RAM and apply overbilling when RAM is constrained.

Recall that $\mathrm{H} 3$ states that hospitals overbill more and use less AEM when AEM is constrained. The coefficient on $\mathrm{NOA}_{t-1}$ is negative and significant in the AEM equation (see Column 5), suggesting that AEM is constrained by hospitals' accounting flexibility. The negative and significant coefficient on $\mathrm{NOA}_{t-1}$ in the RAM equation (see Column 4) shows that hospitals also engage in less RAM if accounting flexibility is constrained. Instead, hospitals overbill more in situations of low accounting flexibility, as evidenced by the positive and significant coefficients on $\mathrm{NOA}_{t-1}$ in the overbilling 79 equation (see Column 1). Thus, in line with $\mathrm{H} 3$, the results show that, if hospitals are constrained in applying AEM, they reduce AEM and overbill more.

The results also provide evidence in support of $\mathrm{H} 4 \mathrm{a}$ and $\mathrm{H} 4 \mathrm{~b}$, which state that hospitals that are constrained from using overbilling cut discretionary expenditures instead. In particular, in 
the overbilling 79 equation (see Column 1), the coefficients on LOG DRG 79 DISCHARGES and SYSTEM are positive, while the coefficients on PROSECUTION and PUBLIC are negative, and significant at $\mathrm{p}<0.10$, indicating that hospitals' operational constraints as well as oversight constrain overbilling. Similar patterns — although weaker in terms of statistical significance — can be observed for overbilling in the other two DRG families. In the RAM equation (see Column 4), the results show that the coefficients on these four variables are significant in opposite directions. ${ }^{14}$ These findings indicate that hospitals with operational constraints on overbilling reduce overbilling and cut discretionary expenditures instead. Hospitals subject to more oversight also reduce overbilling and use RAM and AEM instead. In line with H4, these results show that hospitals use more RAM when overbilling is constrained by operational constraints or regulatory oversight. These results are most pronounced in DRG family 79, which offers the largest financial gains from overbilling.

The controls are in line with prior research. In the RAM and overbilling 79 equation, the coefficient on BENCHMARK is positive and significant, suggesting that hospitals use RAM and overbilling to meet the zero-earnings benchmark. In contrast, the coefficient on BENCHMARK is insignificant in the AEM equation, suggesting that for-profit hospitals do not use AEM to meet this benchmark. Larger hospitals engage in more RAM and less overbilling in DRG family 79; more-profitable hospitals engage in more AEM.

- Table 5 and 6 here -

\section{Conclusions}

\footnotetext{
${ }^{14}$ Note that I report results using LOG DRG 79 DISCHARGES in both the AEM and RAM equations. The inferences are unaffected when using LOG DRG 144 DISCHARGES or LOG DRG 296 DISCHARGES instead.
} 
This paper examines hospitals' earnings management choices of overbilling, managing accruals, or cutting expenditures based on the constraints associated with each strategy. Studying the role of overbilling in hospitals' earnings management decisions is important given the prevalence of overbilling in the healthcare sector, the growing interest in understanding hospitals' earnings management choices, and the importance of this industry.

My results suggest that hospital managers use these manipulation tools as substitutes for each other and choose between them based on the constraints associated with each strategy. In particular, I find that overbilling is least constrained when hospitals face high competition or financial distress. When AEM is constrained because of prior accounting choices, hospitals resort to overbilling instead of RAM. Thus, in contrast to prior research showing that firms use AEM when RAM is constrained and vice versa (e.g., Zang, 2012), I find that hospitals use overbilling instead of AEM or RAM when either of the latter strategies is constrained. On the other hand, my results also indicate that overbilling is constrained by hospitals' operations and regulatory oversight, which result in less overbilling and more RAM.

This study contributes to the accounting literature by providing a more complete picture of the types of earnings management tools that hospitals use to manipulate their performance. While this study focuses on overbilling in the healthcare sector, future research could examine overbilling in other industries. For instance, the large number of lawsuits under the False Claims Act as reported by the Department of Justice (2013) suggests that overbilling is widespread across firms with government contracts. 


\section{References}

Abelson, R. (2002). Market place; Tenet Healthcare says the SEC is looking informally into the fall of Tenet's share price. The New York Times. Retrieved from http://www.nytimes.com/2002/11/19/business/market-place-tenet-healthcare-says-seclooking-informally-into-fall-tenet-s.html.

Allen, E. J., Larson, C. R., \& Sloan, R. G. (2013). Accrual reversals, earnings and stock returns. Journal of Accounting and Economics, 56, 113-129.

Altman, E. I. (1968). Financial ratios, discriminant analysis and the prediction of corporate bankruptcy. Journal of Finance, 23, 589-609.

Altman, E. I., \& Saunders, A. (1997). Credit risk measurement: Developments over the last 20 years. Journal of Banking and Finance, 21, 1721-1742.

Arora, A. (1996). Testing for complementarities in reduced-form regressions: A note. Economics letters, 50, 51-55.

Baber, W. R., Kang, S. H., \& Li, Y. (2011). Modeling discretionary accrual reversal and the balance sheet as an earnings management constraint. Accounting Review, 86, 1189-1212.

Barton, J., \& Simko, P. J. (2002). The balance sheet as an earnings management constraint. Accounting Review, 77, 1-27.

Bazzoli, G. J., Chan, B., Shortell, S. M., \& D'Aunno, T. (2000). The financial performance of hospitals belonging to health networks and systems. Inquiry, 37, 234-252.

Becker, D., Kessler, D., \& McClellan, M. (2005). Detecting Medicare abuse. Journal of Health Economics, 24, 189-210.

Beneish, D. M. (1999). The detection of earnings manipulation. Financial Analysts Journal, 55, 24-36.

Burke, D., Wang, B., Wan, T. T., \& Diana, M. (2002). Exploring hospitals' adoption of information technology. Journal of Medical Systems, 26, 349-355.

Charlson, M. E., Pompei, P., Ales, K. L., \& MacKenzie, C. R. (1987). A new method of classifying prognostic comorbidity in longitudinal studies: Development and validation. Journal of Chronic Diseases, 40, 373-383.

Chen, W., Hribar, P., \& Melessa, S. (2016). Two-step regression analysis and biased estimates in accounting research: An application of the Frisch-Waugh-Lovell Theorem. Unpublished manuscript.

Clemens, J., \& Gottlieb, J. D. (2015). Bargaining in the shadow of a giant: Medicare's influence on private payment systems. Unpublished manuscript.

CMS. (2004). Fiscal year 2004 improper Medicare fee-for-service payment report. Retrieved from: $\quad$ https://www.cms.gov/Research-Statistics-Data-and-Systems/MonitoringPrograms/Medicare-FFS-Compliance-

Programs/CERT/Downloads/FY_2004ShortReport.pdf.

CMS. (2010). Acute care hospital inpatient prospective payment system. Retrieved from: https://www.cms.gov/Outreach-and-Education/Medicare-Learning-NetworkMLN/MLNProducts/downloads/AcutePaymtSysfctsht.pdf.

CMS. (2013). CMS strategy: The road forward. Retrieved from http://www.cms.gov/AboutCMS/Agency-Information/CMS-Strategy/Downloads/CMS-Strategy.pdf. 
Cohen, D. A., Dey, A., \& Lys, T. Z. (2008). Real and accrual-based earnings management in the pre- and post-Sarbanes-Oxley periods. Accounting Review, 83, 757-787.

Congress. (1863). False Claims Act. 31 USC. $\S \S 3729-3733$.

Congress. (1986). False Claims Act. 31 USC. $\S \S 3729-3733$.

Dafny, L. (2005). How do hospitals respond to price changes? American Economic Review, 95, $1525-1547$.

Dafny, L., \& Dranove, D. (2009). Regulatory exploitation and management changes: Upcoding in the hospital industry. Journal of Law and Economics, 52, 223-250.

DeFond, M. L., \& Subramanyam, K. R. (1998). Auditor changes and discretionary accruals. Journal of Accounting and Economics, 25, 35-67.

Degeorge, F., Patel, J., \& Zeckhauser, R. (1999). Earnings management to exceed thresholds. Journal of Business, 72, 1-33.

DOJ. (2013). False Claims Act fraud statistics. Retrieved from https://www.justice.gov/sites/default/files/civil/legacy/2013/12/26/C-

FRAUDS_FCA_Statistics.pdf.

Dranove, D., \& Shanley, M. (1995). Cost reductions or reputation enhancement as motives for mergers: The logic of multihospital systems. Strategic Management Journal, 16, 55-74.

Dranove, D., Shanley, M., \& White, W. D. (1993). Price and concentration in hospital markets: the switch from patient-driven to payer-driven competition. Journal of Law and Economics, 36, 179-204.

Eldenburg, L., Gunny, K. A., Hee, K. W., \& Soderstrom, N. (2011). Earnings management using real activities: Evidence from nonprofit hospitals. Accounting Review, 86, 1605-1630.

Eldenburg, L., Hermalin, B. E., Weisbach, M. S., \& Wosinska, M. (2004). Governance, performance objectives and organizational form: Evidence from hospitals. Journal of Corporate Finance, 10, 527-548.

Eldenburg, L., \& Krishnan, R. (2008). The influence of ownership on accounting information expenditures. Contemporary Accounting Research, 25, 739-772.

GAO. (2000). Medicare improper payments. Retrieved from: http://www.gao.gov/assets/230/229532.pdf.

GAO. (2013). High-risk series: An update. Retrieved from: http://www.gao.gov/assets/660/652133.pdf.

GAO. (2015). Addressing improper payments and the tax gap would improve the government's fiscal position. Retrieved from http://www.gao.gov/assets/680/672884.pdf.

Grabner, I., \& Moers, F. (2013). Management control as a system or a package? Conceptual and empirical issues. Accounting, Organizations and Society, 38, 407-419.

Graham, J. R., Harvey, C. R., \& Rajgopal, S. (2005). The economic implications of corporate financial reporting. Journal of Accounting and Economics, 40, 3-73.

Healy, P. M. (1985). The effect of bonus schemes on accounting decisions. Journal of Accounting and Economics, 7, 85-107.

Healy, P. M., \& Wahlen, J. M. (1999). A review of the earnings management literature and its implications for standard setting. Accounting Horizons, 13, 365-383.

Heese, J., Krishnan, R., \& Moers, F. (2016). Selective regulator decoupling and organizations' strategic responses. Academy of Management Journal, 59, 2178-2204.

HHS. (2013). FY 2013 - Agency financial report. Retrieved from https://www.hhs.gov/sites/default/files/afr/2013-hhs-agency-financial-report.pdf. 
Hoerger, T. J. (1991). Profit variability in for-profit and not-for-profit hospitals. Journal of Health Economics, 10, 259-289.

Jones, J. J. (1991). Earnings management during import relief investigations. Journal of Accounting Research, 29, 193-228.

Krishnan, R., \& Yetman, M. H. (2011). Institutional drivers of reporting decisions in nonprofit hospitals. Journal of Accounting Research, 49, 1001-1039.

Leone, A. J., \& Van Horn, R. L. (2005). How do nonprofit hospitals manage earnings? Journal of Health Economics, 24, 815-837.

Marciukaityte, D., \& Park, J. C. (2009). Market competition and earnings management. Unpublished manuscript.

OIG. (1998). Using software to detect upcoding of hospital bills. Retrieved from https://oig.hhs.gov/oei/reports/oei-01-97-00010.pdf.

OIG. (2001). Medicare hospital prospective payment system: How DRG rates are calculated and updated. Retrieved from: https://oig.hhs.gov/oei/reports/oei-09-00-00200.pdf.

OSHPD. (2011). Financial disclosure report site. Retrieved from https://siera.oshpd.ca.gov/Files/InstructionsAndFAQ.pdf.

Richardson, S. A., Sloan, R. G., Soliman, M. T., \& Tuna, I. (2005). Accrual reliability, earnings persistence and stock prices. Journal of Accounting and Economics, 39, 437-485.

Roomkin, M. J., \& Weisbrod, B. A. (1999). Managerial compensation and incentives in for-profit and nonprofit hospitals. Journal of Law, Economics, and Organization, 15, 750-781.

Roychowdhury, S. (2006). Earnings management through real activities manipulation. Journal of Accounting and Economics, 42, 335-370.

Schipper, K. (1989). Commentary on earnings management. Accounting Horizons, 3, 91-102.

SEC. (2007). SEC charges Tenet Healthcare Corporation and four former senior executives with concealing scheme to meet earnings targets by exploiting Medicare system. Retrieved from: https://www.sec.gov/news/press/2007/2007-60.htm.

SEC. (2013). SEC charges operator of Miami-Dade County's largest hospital with misleading investors about financial condition. Retrieved from: https://www.sec.gov/news/pressrelease/2013-181.

Silverman, E., \& Skinner, J. (2004). Medicare upcoding and hospital ownership. Journal of Health Economics, 23, 369-389.

Soderstrom, N. (1993). Hospital behavior under Medicare incentives. Journal of Accounting and Public Policy, 12, 155-185.

Vansant, B. (2015). Institutional pressures to provide social benefits and the earnings management behavior of nonprofits: Evidence from the U.S. hospital industry. Contemporary Accounting Research, 33, 1576-1600.

Vorst, P. (2016). Real earnings management and long-term operating performance: The role of reversals in discretionary investment cuts. Accounting Review, 91, 1219-1256.

Walsh, M.W. (2007). Blowing the whistle, many times. The New York Times. Retrieved from http://www.nytimes.com/2007/11/18/business/18whistle.html?mcubz=3.

Zang, A. (2012). Evidence on the trade-off between real activities manipulation and accrualbased earnings management. Accounting Review, 87, 675-703. 
Appendix A. Overview of variables

\begin{tabular}{|c|c|}
\hline Variable & Definition \\
\hline \multicolumn{2}{|c|}{ Dependent Variables } \\
\hline Overbilling $\mathrm{X}$ & 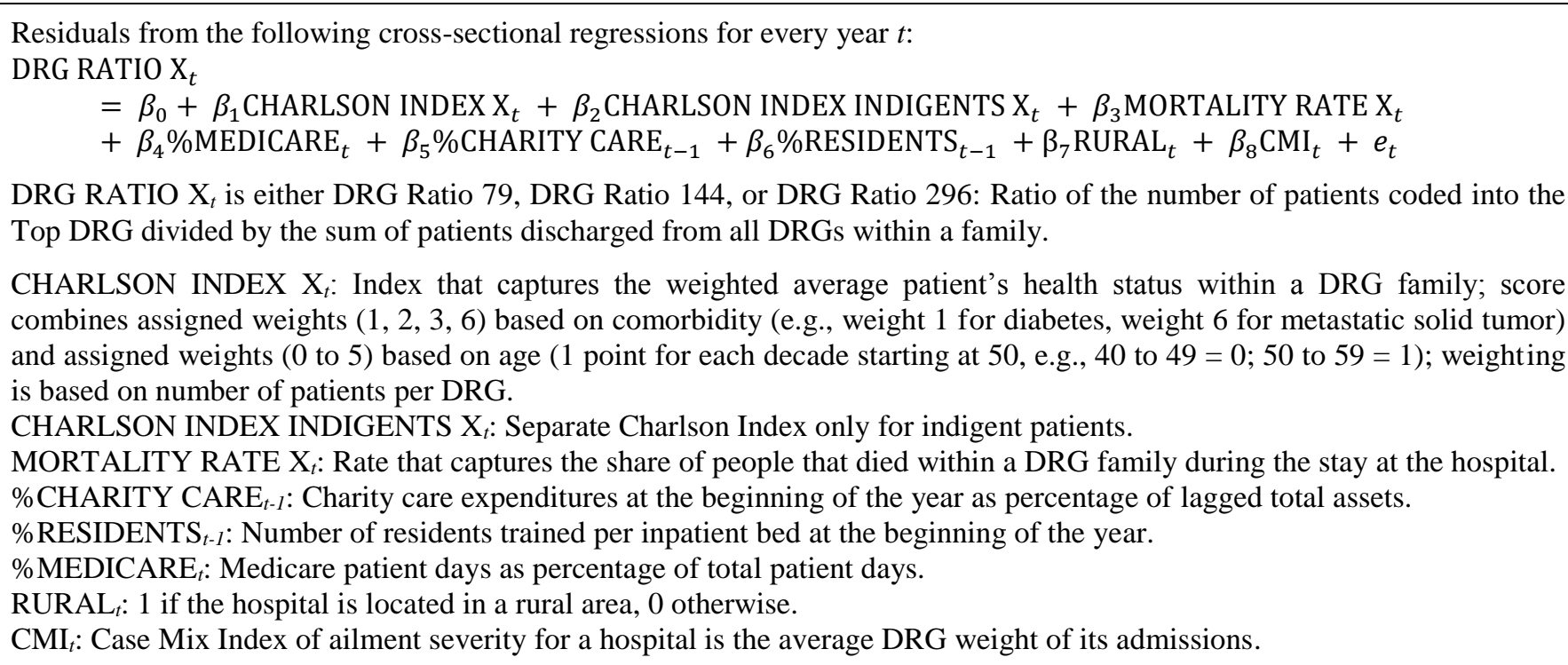 \\
\hline RAM & $\begin{array}{l}\text { Sum of reversed residuals from the following cross-sectional regressions for every year } t \text { : } \\
\operatorname{EXP}_{t}=\beta_{0}+\beta_{1}\left(1 / \mathrm{A}_{t-1}\right)+\beta_{2}\left(\frac{\mathrm{S}_{t-1}}{\mathrm{~A}_{t-1}}\right)+e_{t} \\
\mathrm{NOCC}_{t}=\beta_{0}+\beta_{1}\left(1 / \mathrm{A}_{t-1}\right)+\beta_{2}\left(\frac{\mathrm{S}_{t-1}}{\mathrm{~A}_{t-1}}\right)+e_{t} \\
\mathrm{EXP}_{t} \text { : Expenditures on non-revenue generating activities (i.e., the sum of total research expenditures, total administrative } \\
\text { services, total general services, and total education expenditures) in year } t \text {. } \\
\text { NOCC } \text { : Expenditures on non-operating activities (i.e., the sum of total maintenance expenditures, physicians' offices and } \\
\text { other rental expenditures, total office building expenditures, child care services expenditures, family housing expenditures, } \\
\text { retail operations expenditures, and other non-operating expenditures) in year } t \text {. } \\
\mathrm{A}_{t-1} \text { : Total assets in year } t-1 ; \mathrm{S}_{t-1} \text { : Net revenues in year } t-1 \text {. }\end{array}$ \\
\hline AEM & $\begin{array}{l}\text { Residuals from the following cross-sectional regression for every year } t \text { : } \\
\text { ACCRUALS }_{t} / \mathrm{A}_{t-1}=\beta_{0}+\beta_{1}\left(1 / \mathrm{A}_{t-1}\right)+\beta_{2} \frac{\Delta \mathrm{S}_{t}}{\mathrm{~A}_{t-1}}+\beta_{3} \frac{\mathrm{PPE}_{t}}{\mathrm{~A}_{t-1}}+e_{t}\end{array}$ \\
\hline
\end{tabular}


Operating cash flows divided by total assets.

Following Beneish (1999), the M-Score is calculated as follows: M-SCORE $=-4.84+0.920(\mathrm{DSR})+0.528(\mathrm{GMI})+$ $0.404(\mathrm{AQI})+0.892(\mathrm{SGI})+0.115(\mathrm{DEPI})-0.172(\mathrm{SGAI})+4.679$ (Accruals) $-0.327(\mathrm{LEVI}) . \mathrm{DSR}=\left(\right.$ Receivables $_{t} / \mathrm{Net}$ Patient Revenues $t) /\left(\right.$ Receivables $_{t-1} /$ Net Patient Revenues $\left.t-1\right)$; GMI $=$ Gross Margin trl $_{t} /$ Gross Margin $_{t}$; AQI $=\left[1-\left(\mathrm{PPE}_{t}+\right.\right.$

M-Score

Current Assets $\left.t_{t}\right) /$ Total Assets $\left.t\right] /\left[1-\left(\mathrm{PPE}_{t-1}+\right.\right.$ Current Assets $\left.t-1_{t}\right) /$ Total Assets $\left.t_{t-1}\right] ;$ SGI $=$ Net Patient Revenues $t /$ Net Patient Revenues $t-l ; ; \mathrm{DEPI}=\left[\right.$ Depreciation $_{t-1} /\left(\right.$ Depreciation $\left.\left._{t-1}+\mathrm{PPE}_{t-1}\right)\right] /\left[\right.$ Depreciation $_{t} /\left(\right.$ Depreciation $\left.\left._{t}+\mathrm{PPE}_{t}\right)\right] ; \mathrm{SGAI}=\left(\mathrm{SGA}_{t} /\right.$

Net Patient Revenues $t) /\left(\mathrm{SGA}_{t-1} /\right.$ Net Patient Revenues $\left.s_{t-1}\right)$; Accruals $=($ Income before extraordinary items $t-$ Cash from operations $_{t}$ ) / Total Assets ${ }_{t}$, LEVI $=$ Leverage $_{t} /$ Leverage $_{t-l}$.

\begin{tabular}{|c|c|}
\hline \multicolumn{2}{|c|}{ Constraints associated with Overbilling } \\
\hline Log DRG X Discharges & Natural logarithm of number of discharges in DRG families 79, 144, or 296. \\
\hline System & 1 if the hospital belongs to a system, 0 otherwise. \\
\hline Prosecution & $\begin{array}{l}1 \text { for the years after the last violation year and until two years after the settlement year as reported in the False Claims Act } \\
\text { settlements, } 0 \text { otherwise. }\end{array}$ \\
\hline Public & 1 if the hospital is publicly listed or belongs to a system of publicly listed hospitals, 0 otherwise. \\
\hline \multicolumn{2}{|c|}{ Constraints associated with Real Activities Manipulation } \\
\hline Distress $t-1$ & 1 if Z-Score $<3$ at the beginning of the year, 0 otherwise. \\
\hline $\mathrm{HHI}_{t-1}$ & Herfindahl-Hirshman Index based on market shares of discharges per county at the beginning of the year. \\
\hline \multicolumn{2}{|c|}{ Constraints associated with Accrual-Based Earnings Management } \\
\hline $\mathrm{NOA}_{t-1}$ & $\begin{array}{l}\text { Net operating assets (i.e., equity less cash and marketable securities plus total debt) at the beginning of the year divided by } \\
\text { lagged revenues. }\end{array}$ \\
\hline \multicolumn{2}{|l|}{ Controls } \\
\hline$\%$ Charity Care ${ }_{t-1}$ & Charity care expenditures at the beginning of the year as percentage of lagged total assets. \\
\hline$\%$ Residents $t-1$ & Number of residents trained per inpatient bed at the beginning of the year. \\
\hline Benchmark & 1 if the hospital has just met the zero-earnings benchmark (i.e. 0 to 0.04 based on $2 \mathrm{IQRn}^{-1 / 3}$ ), 0 otherwise. \\
\hline $\mathrm{P} 4 \mathrm{P}$ & 1 if positive $\mathrm{P} 4 \mathrm{P}$ incentives exist, 0 otherwise. \\
\hline \% Medicare & Medicare patient days as percentage of total patient days. \\
\hline Occupancy Rate & Number of patient days scaled by staffed beds times 365 . \\
\hline Log Assets & Natural logarithm of total assets. \\
\hline Log Board Size & Natural logarithm of number of board members. \\
\hline
\end{tabular}


CMI

ROA

Z-Score ${ }_{t-1}$

Rural
Case Mix Index for a hospital is the average DRG weight of its admissions.

Net income divided by total assets.

1.2 times working capital divided by total assets plus 1.4 times retained earnings divided by total assets plus 3.3 times earnings before interest and taxes divided by total assets plus 0.6 times total equity divided by total liabilities plus revenue divided by total assets.

1 if the hospital is located in a rural area, 0 otherwise. 
Table 1. Overview of DRG families

Panel A. Description of DRG families

\begin{tabular}{cclcc}
\hline DRG Family & $\begin{array}{c}\text { DRG } \\
\text { Number } \\
\text { (based on } \\
\text { ICD-9- } \\
\text { CM) }\end{array}$ & \multicolumn{1}{c}{ Description } & $\begin{array}{c}\text { DRG } \\
\text { Weight }^{\mathbf{b}}\end{array}$ & $\begin{array}{c}\text { Revenue } \\
\text { Estimate }^{\mathbf{c}}\end{array}$ \\
$\mathbf{( \$ )}$
\end{tabular}

Notes:

a "TOP" refers to the DRG that generates the highest reimbursement within the DRG family. ICD-9-CM refers to the International Classification of Diseases, Ninth Revision, Clinical Modification. This classification is used to assign diagnostic and procedure codes associated with inpatient, outpatient, and physician office utilization in the U.S.

b Refers to the weight assigned by CMS to each DRG. The weight reflects the average level of resources for an average Medicare patient belonging to the DRG, relative to the average level of resources for all Medicare patients. The weights are intended to account for cost variations between different types of treatments. More expensive conditions are assigned higher DRG weights.

${ }^{\mathrm{c}}$ Refers to the revenue estimate per DRG in dollars calculated as the DRG weight times the average base rate for the year 2005 for a DRG weight of $1(\$ 5,150)$.

This table has been adopted from Heese et al. (2016). 
Panel B. Monetary incentives per DRG family

\begin{tabular}{|c|c|c|c|c|c|c|}
\hline DRG Family & $\begin{array}{c}\text { Difference } \\
\text { between Top } \\
\text { DRG and } \\
\text { Family } \\
\text { Average }^{\mathrm{a}} \\
\end{array}$ & $\begin{array}{c}\text { Average } \\
\text { Payment } \\
\text { Incentive } \\
(\$)^{\mathbf{b}}\end{array}$ & $\begin{array}{c}\text { Max. } \\
\text { Difference }^{\mathrm{c}}\end{array}$ & $\begin{array}{c}\text { Max. } \\
\text { Payment } \\
\text { Incentive } \\
(\$)^{d}\end{array}$ & $\begin{array}{c}\text { Min. } \\
\text { Difference }\end{array}$ & $\begin{array}{c}\text { Min. } \\
\text { Payment } \\
\text { Incentive } \\
(\$)^{\mathrm{f}}\end{array}$ \\
\hline $\begin{array}{c}\text { General Respiratory } \\
\text { Ailments }\end{array}$ & 0.75 & $3,862.50$ & 0.97 & $4,995.50$ & 0.54 & $2,781.00$ \\
\hline $\begin{array}{l}\text { Circulatory system } \\
\text { disorders }\end{array}$ & 0.62 & $3,212.31$ & 0.73 & $3,759.50$ & 0.41 & $2,111.50$ \\
\hline $\begin{array}{c}\text { Diabetes and } \\
\text { nutritional/metabolic } \\
\text { disorders }\end{array}$ & 0.15 & 772.50 & 0.34 & $1,751.00$ & 0.06 & 309.00 \\
\hline
\end{tabular}

\footnotetext{
Notes:

${ }^{\text {a }}$ Computed as the difference between the TOP DRG weight and the average DRG weight in the family.

b Computed as the average difference between TOP DRG weight and family average weight in dollars, i.e., difference in weight times the average base rate for the year 2005 for a DRG weight of $1(\$ 5,150)$.

${ }^{\mathrm{c}}$ Computed as the difference between the TOP DRG weight and the lowest DRG weight in the family.

${ }^{\mathrm{d}}$ Computed as the maximum difference between TOP DRG weight and lowest DRG weight in dollar, i.e., difference in weight times the average base rate for the year 2005 for a DRG weight of $1(\$ 5,150)$.

${ }^{\mathrm{e}}$ Computed as the difference between the TOP DRG weight and the second highest DRG weight in the family.

${ }^{\mathrm{f}}$ Computed as the minimum difference between TOP DRG weight and second highest DRG weight in the family in dollar, i.e., difference in weight times the average base rate for the year 2005 for a DRG weight of $1(\$ 5,150)$.

This table has been adopted from Heese et al. (2016).
} 
Panel C. Overview of discharges in DRG families per hospital and year

\begin{tabular}{|c|c|c|c|c|c|c|c|c|}
\hline Year & $\begin{array}{c}\text { Mean } \\
\text { Number of } \\
\text { Discharges } \\
\text { DRG 79 } \\
\text { Family } \\
\end{array}$ & $\begin{array}{c}\text { DRG 79 } \\
\text { Family } \\
\text { Discharges in } \\
\text { \% of Total } \\
\text { Discharges } \\
\end{array}$ & $\begin{array}{c}\text { Mean Number } \\
\text { of Discharges } \\
\text { DRG } 144 \\
\text { Family }\end{array}$ & $\begin{array}{c}\text { DRG } 144 \\
\text { Family } \\
\text { Discharges in } \\
\text { \% of Total } \\
\text { Discharges } \\
\end{array}$ & $\begin{array}{c}\text { Mean Number } \\
\text { of Discharges } \\
\text { DRG } 296 \\
\text { Family }\end{array}$ & $\begin{array}{c}\text { DRG } 296 \\
\text { Family } \\
\text { Discharges in } \\
\text { \% of Total } \\
\text { Discharges } \\
\end{array}$ & $\begin{array}{l}\text { Mean Number } \\
\text { of Discharges } \\
\text { in all three } \\
\text { DRG Families }\end{array}$ & $\begin{array}{c}\text { All three DRG } \\
\text { Families } \\
\text { Discharges as } \\
\% \text { of Total } \\
\text { Discharges } \\
\end{array}$ \\
\hline 1996 & 178 & 4.1 & 178 & 4.1 & 138 & 3.1 & 494 & 11.2 \\
\hline 1997 & 216 & 4.3 & 201 & 3.9 & 166 & 3.1 & 583 & 11.4 \\
\hline 1998 & 221 & 4.2 & 209 & 4.0 & 176 & 3.3 & 606 & 11.5 \\
\hline 1999 & 239 & 4.3 & 212 & 3.8 & 192 & 3.4 & 643 & 11.5 \\
\hline 2000 & 219 & 3.8 & 219 & 3.8 & 199 & 3.5 & 637 & 11.1 \\
\hline 2001 & 238 & 3.9 & 233 & 3.8 & 223 & 3.6 & 694 & 11.3 \\
\hline 2002 & 226 & 3.6 & 234 & 3.7 & 239 & 3.8 & 699 & 11.0 \\
\hline 2003 & 224 & 4.3 & 214 & 4.2 & 222 & 4.3 & 660 & 12.8 \\
\hline 2004 & 210 & 3.9 & 220 & 4.1 & 225 & 4.2 & 655 & 12.2 \\
\hline 2005 & 266 & 3.9 & 240 & 3.5 & 268 & 3.9 & 774 & 11.4 \\
\hline 2006 & 232 & 3.3 & 232 & 3.3 & 268 & 3.8 & 732 & 10.4 \\
\hline 2007 & 205 & 3.0 & 242 & 3.6 & 253 & 3.7 & 700 & 10.3 \\
\hline Overall & 223 & 3.8 & 219 & 3.8 & 210 & 3.6 & 652 & 11.2 \\
\hline
\end{tabular}

Notes:

The table provides an overview of the mean number of discharges for the DRG families 79, 144, and 296 for the sample hospitals in absolute as well as relative terms. The data are obtained from the Office of Statewide Health Planning and Development (OSHPD). 
Table 2. Descriptive statistics

Panel A. Summary statistics

\begin{tabular}{|c|c|c|c|c|c|}
\hline Variable & Mean & Std. Dev. & $1^{\text {st }}$ Quartile & Median & $3^{\text {rd }}$ Quartile \\
\hline \multicolumn{6}{|c|}{ Constraints associated with Overbilling } \\
\hline Log DRG 79 Discharges & 5.161 & 0.842 & 4.796 & 5.298 & 5.733 \\
\hline Log DRG 144 Discharges & 4.970 & 1.224 & 4.595 & 5.257 & 5.735 \\
\hline Log DRG 296 Discharges & 5.043 & 1.003 & 4.732 & 5.247 & 5.651 \\
\hline System & 0.506 & 0.500 & 0 & 1 & 1 \\
\hline Public & 0.661 & 0.474 & 0 & 1 & 1 \\
\hline Prosecution & 0.039 & 0.194 & 0 & 0 & 0 \\
\hline \multicolumn{6}{|c|}{ Constraints associated with Real Activities Manipulation } \\
\hline $\mathrm{HHI}_{\mathrm{t}-1}$ & 0.096 & 0.112 & 0.021 & 0.055 & 0.115 \\
\hline Distress $_{t-1}$ & 0.246 & 0.431 & 0 & 0 & 0 \\
\hline \multicolumn{6}{|c|}{ Constraints associated with Accrual-Based Earnings Management } \\
\hline $\mathrm{NOA}_{\mathrm{t}-1}$ & 0.292 & 0.205 & 0.166 & 0.241 & 0.357 \\
\hline \multicolumn{6}{|l|}{ Controls } \\
\hline$\%$ Charity Care t-1 & 7.51 & 14.51 & 0 & 1.40 & 7.43 \\
\hline$\%$ Residents $_{\mathrm{t}-1}$ & 0.011 & 0.039 & 0 & 0 & 0 \\
\hline Benchmark & 0.100 & 0.300 & 0 & 0 & 0 \\
\hline $\mathrm{P} 4 \mathrm{P}$ & 0.308 & 0.462 & 0 & 0 & 1 \\
\hline Net Patient Revenues in $000 \mathrm{~s}$ & 59,911 & 53,991 & 24,123 & 40,098 & 76,425 \\
\hline Net Income in $000 \mathrm{~s}$ & 3,328 & 13,075 & $-1,897$ & 517 & 5,323 \\
\hline ROA & 0.003 & 0.191 & -0.079 & 0.021 & 0.116 \\
\hline Occupancy Rate & 0.645 & 0.254 & 0.456 & 0.614 & 0.929 \\
\hline$\%$ Medicare & 43.72 & 17.30 & 32.44 & 44.04 & 54.81 \\
\hline Assets in $000 \mathrm{~s}$ & 62,053 & 83,806 & 15,387 & 34,674 & 74,369 \\
\hline Discharges & 5,816 & 4,352 & 2,806 & 4,910 & 7,588 \\
\hline Board Size & 10.50 & 4.93 & 7 & 11 & 14 \\
\hline CMI & 1.047 & 0.245 & 0.89 & 1.01 & 1.19 \\
\hline Rural & 0.065 & 0.247 & 0 & 0 & 0 \\
\hline
\end{tabular}

Notes:

The table displays the summary statistics for the full sample for the variables over the period 1996-2007. See Appendix A for variable definitions. 
Panel B. Pearson (upper triangle) and Spearman (lower triangle) correlations

\begin{tabular}{|c|c|c|c|c|c|c|c|c|c|c|c|c|c|c|c|c|c|c|c|c|c|c|}
\hline & 1. & 2. & 3. & 4. & 5. & 6. & 7. & 8. & 9. & 10. & 11. & 12. & 13. & 14. & 15. & 16. & 17. & 18. & 19. & 20. & 21. & 22. \\
\hline 1. Overbilling 79 & & 0.20 & 0.27 & -0.17 & -0.08 & 0.16 & 0.06 & 0.02 & -0.12 & -0.33 & 0.13 & 0.11 & -0.12 & -0.04 & -0.05 & 0.04 & -0.03 & -0.10 & -0.21 & -0.01 & 0.01 & -0.15 \\
\hline 2. Overbilling 144 & 0.24 & & 0.15 & -0.09 & -0.06 & -0.02 & 0.14 & 0.04 & -0.05 & -0.10 & 0.00 & 0.11 & -0.13 & 0.05 & 0.01 & 0.05 & -0.03 & -0.05 & 0.00 & -0.04 & 0.03 & -0.03 \\
\hline 3. Overbilling 296 & 0.20 & 0.09 & & -0.09 & -0.02 & 0.09 & 0.01 & -0.01 & -0.10 & -0.10 & 0.05 & 0.05 & -0.01 & -0.03 & 0.02 & 0.02 & -0.01 & -0.04 & -0.06 & -0.00 & 0.02 & -0.04 \\
\hline 4. RAM & -0.16 & -0.03 & -0.09 & & 0.13 & 0.03 & 0.02 & -0.05 & 0.08 & 0.17 & -0.15 & -0.03 & 0.21 & -0.21 & -0.04 & 0.06 & -0.02 & 0.11 & 0.16 & 0.13 & 0.02 & -0.02 \\
\hline 5. AEM & -0.10 & -0.06 & -0.01 & 0.11 & & 0.05 & 0.07 & 0.06 & 0.07 & 0.06 & -0.06 & -0.09 & 0.09 & 0.01 & 0.08 & -0.02 & 0.02 & 0.04 & 0.08 & 0.29 & 0.00 & 0.04 \\
\hline $\begin{array}{l}\text { 6. Log DRG } 79 \\
\text { Discharges }\end{array}$ & 0.13 & -0.00 & 0.02 & 0.06 & 0.04 & & 0.87 & 0.88 & 0.08 & -0.16 & -0.22 & -0.22 & 0.31 & -0.04 & -0.04 & -0.06 & 0.02 & 0.36 & 0.55 & 0.20 & 0.29 & 0.16 \\
\hline $\begin{array}{l}\text { 7. Log DRG } 144 \\
\text { Discharges }\end{array}$ & 0.08 & 0.12 & 0.06 & 0.08 & 0.10 & 0.81 & & 0.89 & 0.09 & -0.12 & -0.23 & -0.14 & 0.27 & 0.01 & -0.01 & -0.01 & 0.08 & 0.38 & 0.56 & 0.16 & 0.28 & 0.15 \\
\hline $\begin{array}{l}\text { 8. Log DRG } 296 \\
\text { Discharges }\end{array}$ & 0.01 & 0.02 & -0.03 & 0.00 & 0.09 & 0.81 & 0.83 & & 0.11 & -0.19 & -0.24 & -0.19 & 0.21 & 0.11 & 0.05 & -0.02 & 0.07 & 0.36 & 0.55 & 0.11 & 0.35 & 0.18 \\
\hline 9. Prosecution & -0.12 & -0.05 & -0.10 & 0.10 & 0.10 & 0.08 & 0.11 & 0.14 & & 0.04 & -0.10 & -0.07 & 0.15 & 0.04 & 0.01 & -0.04 & 0.06 & 0.12 & 0.19 & 0.09 & 0.18 & 0.01 \\
\hline 10. $\mathrm{HHI}_{\mathrm{t}-1}$ & -0.38 & -0.12 & -0.09 & 0.16 & 0.05 & 0.03 & 0.07 & 0.01 & -0.01 & & 0.02 & 0.03 & 0.11 & -0.12 & -0.07 & 0.04 & -0.02 & 0.09 & 0.08 & 0.02 & -0.08 & 0.05 \\
\hline 11. Distress $\mathrm{t}_{\mathrm{t}-1}$ & 0.11 & 0.00 & 0.04 & -0.15 & -0.08 & -0.25 & -0.25 & -0.29 & -0.10 & 0.00 & & 0.28 & -0.25 & -0.12 & -0.06 & -0.00 & -0.18 & -0.24 & -0.26 & -0.27 & -0.24 & -0.12 \\
\hline 12. $\mathrm{NOA}_{t-1}$ & 0.07 & 0.12 & 0.05 & 0.09 & -0.03 & -0.18 & -0.11 & -0.23 & -0.06 & 0.13 & 0.41 & & -0.03 & -0.32 & -0.10 & 0.08 & -0.07 & -0.15 & 0.08 & 0.02 & -0.14 & -0.16 \\
\hline 13. Public & -0.11 & -0.11 & -0.01 & 0.20 & 0.10 & 0.27 & 0.28 & 0.21 & 0.15 & 0.20 & -0.25 & 0.08 & & -0.08 & -0.09 & -0.01 & 0.25 & 0.35 & 0.48 & 0.12 & 0.47 & -0.08 \\
\hline 14. \%Charity Care ${ }_{t-1}$ & -0.09 & 0.03 & -0.07 & -0.09 & -0.00 & 0.15 & 0.17 & $\mathbf{0 . 3 0}$ & 0.13 & -0.01 & -0.20 & -0.41 & 0.10 & & 0.01 & -0.02 & 0.04 & -0.01 & -0.09 & -0.06 & 0.21 & 0.03 \\
\hline 15. \% Resident $\mathrm{s}_{\mathrm{t}-1}$ & -0.03 & 0.00 & 0.01 & -0.06 & 0.05 & 0.02 & 0.02 & 0.11 & 0.04 & -0.17 & -0.05 & -0.14 & -0.10 & -0.01 & & 0.01 & -0.11 & 0.08 & 0.12 & 0.05 & 0.02 & 0.14 \\
\hline 16. Benchmark & 0.05 & 0.04 & 0.02 & 0.05 & -0.05 & -0.07 & -0.06 & -0.05 & -0.05 & 0.01 & -0.06 & 0.06 & -0.01 & -0.05 & 0.01 & & -0.03 & -0.00 & 0.03 & 0.03 & 0.01 & -0.02 \\
\hline 17. $\mathrm{P} 4 \mathrm{P}$ & -0.01 & -0.01 & -0.02 & -0.03 & 0.07 & 0.03 & 0.06 & 0.08 & 0.06 & -0.12 & -0.18 & -0.09 & 0.25 & 0.14 & -0.00 & -0.04 & & 0.03 & 0.11 & -0.01 & 0.22 & -0.09 \\
\hline 18. Log Board Size & -0.15 & -0.04 & -0.04 & 0.16 & 0.07 & 0.46 & 0.44 & 0.40 & 0.14 & 0.22 & -0.27 & -0.06 & 0.35 & 0.04 & 0.08 & -0.02 & -0.01 & & 0.43 & 0.13 & 0.32 & 0.14 \\
\hline 19. Log Assets & -0.19 & 0.00 & -0.07 & 0.25 & 0.13 & 0.58 & 0.61 & 0.62 & 0.20 & 0.17 & -0.24 & 0.22 & 0.47 & 0.14 & 0.07 & -0.00 & 0.11 & 0.49 & & 0.34 & 0.48 & 0.20 \\
\hline 20. ROA & -0.05 & -0.05 & -0.02 & 0.16 & 0.33 & 0.20 & 0.23 & 0.20 & 0.11 & 0.01 & -0.28 & 0.08 & 0.14 & 0.01 & 0.01 & -0.02 & 0.01 & 0.16 & 0.33 & & 0.11 & 0.10 \\
\hline 21. System & 0.02 & 0.01 & 0.00 & 0.06 & 0.02 & 0.28 & 0.18 & 0.32 & 0.19 & -0.07 & -0.24 & -0.08 & 0.47 & 0.31 & 0.10 & 0.01 & 0.23 & $\mathbf{0 . 3 0}$ & 0.42 & 0.15 & & -0.17 \\
\hline 22. Occupancy Rate & -0.17 & -0.06 & -0.07 & -0.01 & 0.07 & 0.23 & 0.28 & 0.27 & 0.00 & 0.11 & -0.11 & -0.18 & -0.09 & 0.14 & 0.05 & -0.05 & -0.10 & 0.18 & 0.19 & 0.07 & -0.19 & \\
\hline
\end{tabular}

\section{Notes:}

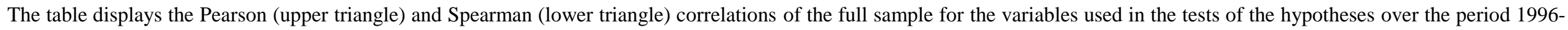
2007. See Appendix A for variable definitions. Bold values indicate significance levels at $p<0.1$ (two-tailed). 
Table 3. Measurement of overbilling, real activities manipulation and accrual-based earnings management

Panel A. Estimation of the normal levels of accruals, discretionary expenditures and billing

\begin{tabular}{|c|c|c|c|c|c|c|}
\hline Variables & $\begin{array}{c}\text { (1) } \\
\text { DRG Ratio } \\
79_{\mathrm{t}}\end{array}$ & $\begin{array}{c}(2) \\
\text { DRG Ratio } \\
\text { 144 }_{t}\end{array}$ & $\begin{array}{c}\text { (3) } \\
\text { DRG Ratio } \\
\text { 296 }\end{array}$ & $\begin{array}{c}(4) \\
\operatorname{EXP}_{t} / A_{t-1}\end{array}$ & $\begin{array}{c}(5) \\
\operatorname{NOCC}_{t} / A_{t-1}\end{array}$ & $\begin{array}{c}\text { (6) } \\
\text { Accrualst } / A_{t-1}\end{array}$ \\
\hline & Coefficient & Coefficient & Coefficient & & Coefficient & Coefficient \\
\hline Intercept & $\begin{array}{l}0.158 * * * \\
(<0.001)\end{array}$ & $\begin{array}{c}-0.016 \\
(0.52)\end{array}$ & $\begin{array}{l}0.143 * * * \\
(<0.001)\end{array}$ & $\begin{array}{c}0.038^{* * *} \\
(0.046)\end{array}$ & $\begin{array}{c}0.005^{* *} \\
(0.028)\end{array}$ & $\begin{array}{c}0.001 \\
(0.967)\end{array}$ \\
\hline Charlson Index X & $\begin{array}{l}0.016 \\
(0.14)\end{array}$ & $\begin{array}{l}0.003 \\
(0.78)\end{array}$ & $\begin{array}{l}0.040 * * * \\
(<0.001)\end{array}$ & & & \\
\hline $\begin{array}{l}\text { Charlson Index } \\
\text { Indigents X }\end{array}$ & -0.003 & -0.006 & $0.011 * * *$ & & & \\
\hline Mortality Rate X & $\begin{array}{c}(0.33) \\
0.671^{* *} \\
(0.02)\end{array}$ & $\begin{array}{c}(0.15) \\
1.415^{* * * *} \\
(0.01)\end{array}$ & $\begin{array}{c}(<0.001) \\
0.526^{*} \\
(0.08)\end{array}$ & & & \\
\hline$\%$ Charity Care C $_{t-1}$ & $\begin{array}{c}0.082 * * \\
(0.02)\end{array}$ & $\begin{array}{c}0.074 * * * * \\
(0.01)\end{array}$ & $\begin{array}{l}0.065 \\
(0.14)\end{array}$ & & & \\
\hline$\%$ Residents $_{\mathrm{t}-1}$ & $\begin{array}{c}0.459 * * * \\
(<0.001)\end{array}$ & $\begin{array}{l}0.166^{*} \\
(0.09)\end{array}$ & $\begin{array}{l}0.063 \\
(0.44)\end{array}$ & & & \\
\hline$\%$ Medicare & $\begin{array}{l}0.210 * * * \\
(<0.001)\end{array}$ & $\begin{array}{c}-0.012 \\
(0.76)\end{array}$ & $\begin{array}{c}0.091 * * \\
(0.02)\end{array}$ & & & \\
\hline Rural & $\begin{array}{c}-0.063 * * * \\
(<0.001)\end{array}$ & $\begin{array}{c}-0.040 * * * \\
(<0.001)\end{array}$ & $\begin{array}{c}-0.005 \\
(0.82)\end{array}$ & & & \\
\hline CMI & $\begin{array}{l}0.004 \\
(0.94)\end{array}$ & $\begin{array}{c}0.114 * * * \\
(<0.001)\end{array}$ & $\begin{array}{l}0.035 \\
(0.16)\end{array}$ & & & \\
\hline $1 / A_{t-1}$ & & & & $\begin{array}{l}0.465^{*} \\
(0.084)\end{array}$ & $\begin{array}{c}-0.013 * * \\
(0.017)\end{array}$ & $\begin{array}{l}-0.164 \\
(0.392)\end{array}$ \\
\hline $\mathrm{S}_{\mathrm{t}-1} / \mathrm{A}_{\mathrm{t}-1}$ & & & & $\begin{array}{l}0.271 * * * \\
(<0.001)\end{array}$ & $\begin{array}{c}0.006 * * * \\
(0.004)\end{array}$ & \\
\hline$\Delta \mathrm{S}_{\mathrm{t}} / \mathrm{A}_{\mathrm{t}-1}$ & & & & & & $\begin{array}{l}0.093 * \\
(0.051)\end{array}$ \\
\hline $\mathrm{PPE}_{\mathrm{t}} / \mathrm{A}_{\mathrm{t}-1}$ & & & & & & $\begin{array}{c}-0.200 * * \\
(0.027)\end{array}$ \\
\hline Mean adjusted $\mathrm{R}^{2}$ & 0.373 & 0.348 & 0.318 & 0.736 & 0.055 & 0.121 \\
\hline $\begin{array}{l}\text { Mean Number of } \\
\text { Observations }\end{array}$ & 83.67 & 83.67 & 83.67 & 76.08 & 76.08 & 82.17 \\
\hline
\end{tabular}

\section{Notes:}

This table presents the estimation of the normal levels of billing in the DRG families 79, 144, and 296, the normal levels of expenditures as well as accruals. The regressions are estimated cross-sectionally for each year for the period 1996-2007 using OLS estimation technique. The reported coefficients are the mean values of the coefficients across years and the adjusted $\mathrm{R}^{2}$ is the mean adjusted $\mathrm{R}^{2}$ across years. $p$-values in parentheses, $* * * p<0.01, * * p<0.05$, * $p<0.1$ (two-tailed), variables are winsorized at $1 \%$ and $99 \%$ levels. See Appendix A for variable definitions. 
Panel B. Summary statistics for overbilling, real activities manipulation and accrual-based earnings management

\begin{tabular}{lccccc}
\hline Variable & Mean & Std. Dev. & $\mathbf{1}^{\text {st }}$ Quartile & Median & $\mathbf{3}^{\text {rd }}$ Quartile \\
\hline Overbilling 79 & -0.0002 & 0.120 & -0.060 & -0.003 & 0.071 \\
Overbilling 144 & -0.0004 & 0.073 & -0.047 & -0.013 & 0.026 \\
Overbilling 296 & 0.0013 & 0.087 & -0.034 & 0.018 & 0.077 \\
RAM & -0.0005 & 0.129 & -0.046 & 0.021 & 0.070 \\
AEM & -0.0002 & 0.228 & -0.095 & 0.011 & 0.101 \\
\hline
\end{tabular}

Notes:

Overbilling 79, 144, and 296, and AEM are the estimated residuals from Models (1)-(3) and (6) presented in Table 3, panel A, respectively. RAM is the sum of the estimated residuals from Models (4) and (5) multiplied by -1 . The table displays the summary statistics of the full sample for the earnings management variables over the period 1996-2007.

Panel C. Pearson (upper triangle) and Spearman (lower triangle) correlations

\begin{tabular}{lccccc}
\hline & Overbilling 79 & Overbilling 144 & Overbilling 296 & RAM & AEM \\
\hline Overbilling 79 & & $0.20^{* * *}$ & $0.27^{* * *}$ & $-0.17^{* * *}$ & $-0.08^{* *}$ \\
Overbilling 144 & $0.24 * * *$ & & $0.15^{* * *}$ & $-0.09^{* * *}$ & $-0.06^{*}$ \\
Overbilling 296 & $0.20^{* * *}$ & $0.09^{* *}$ & & $-0.09^{* * *}$ & -0.02 \\
RAM & $-0.16^{* * *}$ & -0.03 & $-0.09^{* * *}$ & & $0.13^{* * *}$ \\
AEM & $-0.10^{* *}$ & $-0.06^{*}$ & -0.01 & $0.11^{* * *}$ & \\
\hline
\end{tabular}

Notes:

The table displays the Pearson (upper triangle) and Spearman (lower triangle) correlations for the earnings management variables. See Appendix A for variable definitions.

Panel D. Pearson correlations of overbilling, real activities manipulation and accrual-based earnings management in year $t$ and year $t+1$

\begin{tabular}{|c|c|c|c|c|c|}
\hline & Overbilling $79_{t+1}$ & Overbilling $144_{t+1}$ & Overbilling $296_{t+1}$ & $\mathbf{R A M}_{t+1}$ & $\mathbf{A E M}_{t+1}$ \\
\hline Overbilling 79 & $0.75 * * *$ & & & & \\
\hline Overbilling 144 & & $0.60^{* * *}$ & & & \\
\hline Overbilling 296 & & & $0.63^{* * *}$ & & \\
\hline RAM & & & & $0.29 * * *$ & \\
\hline AEM & & & & & -0.04 \\
\hline
\end{tabular}

Notes:

The table displays the Pearson correlations for the earnings management variables in year $t$ and year $t+1$. See Appendix A for variable definitions. 
Table 4. OLS model of overbilling on M-Score and cash flow

\begin{tabular}{|c|c|c|c|c|c|c|}
\hline Variables & $\begin{array}{c}\text { (1) } \\
\text { M-Score }\end{array}$ & $\begin{array}{c}(2) \\
\text { M-Score } \\
\end{array}$ & $\begin{array}{c}\text { (3) } \\
\text { M-Score } \\
\end{array}$ & $\begin{array}{c}\text { (4) } \\
\text { CFO }\end{array}$ & $\begin{array}{c}(5) \\
\text { CFO }\end{array}$ & $\begin{array}{c}(6) \\
\text { CFO }\end{array}$ \\
\hline Overbilling X & $\begin{array}{c}0.633^{*} \\
(0.08)\end{array}$ & $\begin{array}{c}1.529 * * \\
(0.03)\end{array}$ & $\begin{array}{l}0.428 \\
(0.27)\end{array}$ & $\begin{array}{c}0.515^{* *} \\
(0.02)\end{array}$ & $\begin{array}{c}0.329^{*} \\
(0.10)\end{array}$ & $\begin{array}{l}0.034 \\
(0.77)\end{array}$ \\
\hline \multicolumn{7}{|l|}{ Controls } \\
\hline ROA & $\begin{array}{c}0.553 * * \\
(0.02)\end{array}$ & $\begin{array}{c}0.553 * * \\
(0.02)\end{array}$ & $\begin{array}{c}0.487 * * \\
(0.03)\end{array}$ & $\begin{array}{c}0.534 * * * \\
(<0.001)\end{array}$ & $\begin{array}{l}0.547 * * * \\
(<0.001)\end{array}$ & $\begin{array}{l}0.525 * * * \\
(<0.001)\end{array}$ \\
\hline Z-Score $_{t-1}$ & $\begin{array}{l}0.011 \\
(0.38)\end{array}$ & $\begin{array}{l}0.008 \\
(0.51)\end{array}$ & $\begin{array}{l}0.005 \\
(0.68)\end{array}$ & $\begin{array}{l}0.005 \\
(0.21)\end{array}$ & $\begin{array}{l}0.003 \\
(0.45)\end{array}$ & $\begin{array}{l}0.003 \\
(0.43)\end{array}$ \\
\hline $\mathrm{HHI}_{\mathrm{t}-1}$ & $\begin{array}{l}0.346 \\
(0.43)\end{array}$ & $\begin{array}{l}0.201 \\
(0.56)\end{array}$ & $\begin{array}{l}0.237 \\
(0.55)\end{array}$ & $\begin{array}{c}0.198 * * \\
(0.04)\end{array}$ & $\begin{array}{c}0.146^{*} \\
(0.09)\end{array}$ & $\begin{array}{l}0.108 \\
(0.15)\end{array}$ \\
\hline Log Assets & $\begin{array}{l}0.028 \\
(0.57)\end{array}$ & $\begin{array}{l}0.022 \\
(0.68)\end{array}$ & $\begin{array}{l}0.021 \\
(0.69)\end{array}$ & $\begin{array}{c}-0.040 * * * \\
(0.01)\end{array}$ & $\begin{array}{c}-0.049 * * * \\
(0.01)\end{array}$ & $\begin{array}{c}-0.044 * * * \\
(0.01)\end{array}$ \\
\hline Log Board Size & $\begin{array}{l}0.104 \\
(0.35)\end{array}$ & $\begin{array}{l}0.120 \\
(0.31)\end{array}$ & $\begin{array}{l}0.101 \\
(0.41)\end{array}$ & $\begin{array}{c}-0.006 \\
(0.69)\end{array}$ & $\begin{array}{c}-0.001 \\
(0.93)\end{array}$ & $\begin{array}{c}-0.002 \\
(0.91)\end{array}$ \\
\hline System & $\begin{array}{c}-0.002 \\
(0.99)\end{array}$ & $\begin{array}{c}-0.002 \\
(0.90)\end{array}$ & $\begin{array}{c}-0.003 \\
(0.83)\end{array}$ & $\begin{array}{c}-0.011 \\
(0.63)\end{array}$ & $\begin{array}{c}-0.001 \\
(0.97)\end{array}$ & $\begin{array}{r}-0.003 \\
(0.88)\end{array}$ \\
\hline Intercept & $\begin{array}{c}-0.833 \\
(0.29)\end{array}$ & $\begin{array}{c}-0.790 \\
(0.37)\end{array}$ & $\begin{array}{c}-0.532 \\
(0.49)\end{array}$ & $\begin{array}{c}0.686^{* * * *} \\
(0.01)\end{array}$ & $\begin{array}{c}0.887^{* * * *} \\
(0.01)\end{array}$ & $\begin{array}{c}0.804 * * * \\
(0.01)\end{array}$ \\
\hline Year FE & Yes & Yes & Yes & Yes & Yes & Yes \\
\hline SE clustered by & Hospital & Hospital & Hospital & Hospital & Hospital & Hospital \\
\hline Observations & 902 & 902 & 902 & 902 & 902 & 902 \\
\hline Adjusted $\mathrm{R}^{2}$ & 0.028 & 0.033 & 0.032 & 0.109 & 0.095 & 0.086 \\
\hline
\end{tabular}

Notes:

The models presented differ in the dependent variables used. Columns 1-3 use the M-Score and Columns 4-6 use $C F O$, i.e., operating cash flow divided by beginning of the year total assets. The models also differ in the Overbilling measure included. Columns 1 and 4 include Overbilling 79, Columns 2 and 5 include Overbilling 144, and Columns 3 and 6 include Overbilling 296. The results reported are from an OLS regression estimation. $p$-values in parentheses, *** $p<0.01, * * p<0.05, * p<0.1$ (two-tailed), variables are winsorized at $1 \%$ and $99 \%$ levels. See Appendix A for variable definitions. 
Table 5. OLS model of choice between overbilling, real activities manipulation, and accrual-based earnings management

\begin{tabular}{|c|c|c|c|c|c|}
\hline Variables & $\begin{array}{c}\text { (1) } \\
\text { Overbilling } 79\end{array}$ & $\begin{array}{c}(2) \\
\text { Overbilling } 144 \\
\end{array}$ & $\begin{array}{c}(3) \\
\text { Overbilling } 296 \\
\end{array}$ & $\begin{array}{c}(4) \\
\text { RAM } \\
\end{array}$ & $\begin{array}{c}\text { (5) } \\
\text { AEM } \\
\end{array}$ \\
\hline \multicolumn{6}{|c|}{ Constraints associated with Overbilling } \\
\hline Log DRG X Discharges & $\begin{array}{c}0.021 * * * \\
(0.01)\end{array}$ & $\begin{array}{l}0.011 * \\
(0.09)\end{array}$ & $\begin{array}{l}0.009 \\
(0.26)\end{array}$ & $\begin{array}{c}-0.028 * * * \\
(<0.001)\end{array}$ & $\begin{array}{c}-0.007 \\
(0.54)\end{array}$ \\
\hline System & $\begin{array}{c}0.028 * \\
(0.06)\end{array}$ & $\begin{array}{l}0.006 \\
(0.62)\end{array}$ & $\begin{array}{l}0.006 \\
(0.69)\end{array}$ & $\begin{array}{c}-0.032 * * \\
(0.03)\end{array}$ & $\begin{array}{c}-0.037 * * \\
(0.02)\end{array}$ \\
\hline Prosecution & $\begin{array}{c}-0.035^{* * *} \\
(0.02)\end{array}$ & $\begin{array}{c}-0.017 * \\
(0.09)\end{array}$ & $\begin{array}{c}-0.054 * * * \\
(<0.001)\end{array}$ & $\begin{array}{c}0.042 * * \\
(0.03)\end{array}$ & $\begin{array}{c}0.077 * * \\
(0.03)\end{array}$ \\
\hline Public & $\begin{array}{c}-0.026 * \\
(0.09)\end{array}$ & $\begin{array}{c}-0.022 * * \\
(0.03)\end{array}$ & $\begin{array}{c}-0.011 \\
(0.42)\end{array}$ & $\begin{array}{c}0.045 * * \\
(0.02)\end{array}$ & $\begin{array}{c}0.038 * \\
(0.07)\end{array}$ \\
\hline \multicolumn{6}{|c|}{ Constraints associated with Real Activities Manipulation } \\
\hline $\mathrm{HHI}_{\mathrm{t}-1}$ & $\begin{array}{c}-0.313 * * * \\
(<0.001)\end{array}$ & $\begin{array}{c}-0.040 \\
(0.46)\end{array}$ & $\begin{array}{c}-0.088^{*} \\
(0.06)\end{array}$ & $\begin{array}{l}0.078^{*} \\
(0.10)\end{array}$ & $\begin{array}{l}0.030 \\
(0.56)\end{array}$ \\
\hline Distress $_{t-1}$ & $\begin{array}{c}0.025^{*} \\
(0.09)\end{array}$ & $\begin{array}{l}0.003 \\
(0.65)\end{array}$ & $\begin{array}{l}0.006 \\
(0.58)\end{array}$ & $\begin{array}{c}-0.034 * * \\
(0.02)\end{array}$ & $\begin{array}{c}0.062 * * \\
(0.02)\end{array}$ \\
\hline \multicolumn{6}{|c|}{ Constraints associated with Accrual-Based Earnings Management } \\
\hline $\mathrm{NOA}_{\mathrm{t}-1}$ & $\begin{array}{c}0.026 * * \\
(0.04)\end{array}$ & $\begin{array}{l}0.008 \\
(0.53) \\
\end{array}$ & $\begin{array}{l}0.001 \\
(0.88) \\
\end{array}$ & $\begin{array}{c}-0.060^{*} \\
(0.08)\end{array}$ & $\begin{array}{c}-0.136 * * \\
(0.02)\end{array}$ \\
\hline \multicolumn{6}{|l|}{ Controls } \\
\hline Occupancy Rate & $\begin{array}{c}-0.021 \\
(0.38)\end{array}$ & $\begin{array}{c}-0.017 \\
(0.32)\end{array}$ & $\begin{array}{c}-0.008 \\
(0.68)\end{array}$ & $\begin{array}{c}-0.024 \\
(0.34)\end{array}$ & $\begin{array}{l}0.154 \\
(0.56)\end{array}$ \\
\hline Benchmark & $\begin{array}{c}0.027 * * \\
(0.02)\end{array}$ & $\begin{array}{l}0.006 \\
(0.32)\end{array}$ & $\begin{array}{l}0.010 \\
(0.25)\end{array}$ & $\begin{array}{c}0.017 * \\
(0.10)\end{array}$ & $\begin{array}{c}-0.007 \\
(0.63)\end{array}$ \\
\hline $\mathrm{P} 4 \mathrm{P}$ & $\begin{array}{c}-0.003 \\
(0.84)\end{array}$ & $\begin{array}{c}-0.003 \\
(0.77)\end{array}$ & $\begin{array}{c}-0.002 \\
(0.88)\end{array}$ & $\begin{array}{c}-0.031 * * \\
(0.03)\end{array}$ & $\begin{array}{l}0.014 \\
(0.25)\end{array}$ \\
\hline Log Board Size & $\begin{array}{l}0.004 \\
(0.78)\end{array}$ & $\begin{array}{l}0.000 \\
(0.96)\end{array}$ & $\begin{array}{l}0.004 \\
(0.72)\end{array}$ & $\begin{array}{l}0.005 \\
(0.52)\end{array}$ & $\begin{array}{c}-0.001 \\
(0.94)\end{array}$ \\
\hline Log Assets & $\begin{array}{c}-0.019 * * \\
(0.04)\end{array}$ & $\begin{array}{c}0.013 * \\
(0.06)\end{array}$ & $\begin{array}{c}-0.006 \\
(0.47)\end{array}$ & $\begin{array}{l}0.031 * * * \\
(<0.001)\end{array}$ & $\begin{array}{l}0.004 \\
(0.78)\end{array}$ \\
\hline ROA & $\begin{array}{l}0.015 \\
(0.60)\end{array}$ & $\begin{array}{c}-0.014 \\
(0.46)\end{array}$ & $\begin{array}{c}-0.024 \\
(0.32)\end{array}$ & $\begin{array}{l}0.017 \\
(0.65)\end{array}$ & $\begin{array}{c}0.406 * * * \\
(<0.001)\end{array}$ \\
\hline Intercept & $\begin{array}{c}0.358 * * \\
(0.02)\end{array}$ & $\begin{array}{c}-0.131 \\
(0.16)\end{array}$ & $\begin{array}{l}0.086 \\
(0.40)\end{array}$ & $\begin{array}{c}-0.370 * * * \\
(0.01)\end{array}$ & $\begin{array}{l}0.010 \\
(0.95)\end{array}$ \\
\hline Year FE & Yes & Yes & Yes & Yes & Yes \\
\hline SE clustered by & Hospital & Hospital & Hospital & Hospital & Hospital \\
\hline Observations & 902 & 902 & 902 & 902 & 902 \\
\hline Adjusted $\mathrm{R}^{2}$ & 0.304 & 0.091 & 0.145 & 0.130 & 0.136 \\
\hline
\end{tabular}




\section{Notes:}

The models differ in the dependent variables used. In Columns 1-3, the dependent variables are the three overbilling measures, i.e., Overbilling 79, 144, and 296, respectively, which are the estimated residuals from Columns 1-3 presented in Table 3, panel A. The dependent variable in Column 4 is the sum of the estimated residuals from Columns 4 and 5 multiplied by -1 presented in Table 3, panel A. The dependent variable in Column 5 is the estimated residuals from Column 6 presented in Table 3, panel A. The results reported are from an OLS regression estimation. $p$-values in parentheses, $* * * p<0.01, * * p<0.05$, * $p<0.1$ (two-tailed), variables are winsorized at $1 \%$ and $99 \%$ levels. See Appendix A for variable definitions. 
Table 6. The relation between overbilling, real activities manipulation, and accrual-based earnings management

Panel A. Relation between overbilling and real activities manipulation

\begin{tabular}{lcc}
\hline & $(\mathbf{1})$ & $(2)$ \\
& RAM & RAM \\
\hline Overbilling 79 & $-0.115^{*}$ & $-0.075^{* *}$ \\
& $(0.09)$ & $(0.03)$ \\
Overbilling 144 & $-0.122^{*}$ & $-0.054^{*}$ \\
& $(0.08)$ & $(0.10)$ \\
Overbilling 296 & $-0.111^{*}$ & -0.046 \\
& $(0.08)$ & $(0.17)$ \\
\hline
\end{tabular}

\section{Notes:}

The table displays the relation between the realized levels of overbilling with RAM in Column 1 and the conditional correlations of overbilling with RAM in Column 2. The results presented in Column 1 are obtained from including either Overbilling 79, 144, or 296 in the model presented in Column 4 in Table 5. The conditional correlations are the correlations of the residuals from Columns 1-3 with the residuals from Column 4 presented in Table 5. $p$-values in parentheses, $* * * p<0.01, * * p<0.05, * p<0.1$ (two-tailed), variables are winsorized at $1 \%$ and $99 \%$ levels.

Panel B. Relation between overbilling, real activities manipulation, and accrual-based earnings management

\begin{tabular}{lcc}
\hline & $(\mathbf{1})$ & $(\mathbf{2})$ \\
& AEM & AEM \\
\hline Overbilling 79 & $-0.146^{* *}$ & $-0.119^{*}$ \\
Overbilling 144 & $(0.04)$ & $(0.09)$ \\
& $-0.230^{*}$ & $-0.256^{*}$ \\
Overbilling 296 & $(0.10)$ & $(0.08)$ \\
& -0.091 & -0.077 \\
RAM & $(0.28)$ & $(0.41)$ \\
& $0.164^{* *}$ & $0.202^{* *}$ \\
\hline
\end{tabular}

\section{Notes:}

The table displays the relation between the realized levels of overbilling and RAM with AEM in Column 1 and the relation between the unexpected levels of overbilling and RAM with AEM in Column 2. The unexpected levels of overbilling and RAM are the residuals from the models presented in Columns 1-4 in Table 5. The results presented are obtained when including separately (realized as well as unexpected) overbilling 79, 144, or 296 together with RAM in the AEM model (i.e., Column 5 presented in Table 5). The RAM coefficient is obtained when Overbilling 79 is included in the AEM equation. $p$-values in parentheses, *** $p<0.01, * * p<0.05, * p<0.1$ (two-tailed), variables are winsorized at $1 \%$ and $99 \%$ levels. 